Article

\title{
Origin and Residence Time of Groundwater in the Shallow Coastal Aquifer of Eastern Dahomey Basin, Southwestern Nigeria, Using $\delta^{18} \mathrm{O}$ and $\delta \mathrm{D}$ Isotopes
}

\author{
Jamiu A. Aladejana $1,2, * \mathbb{C}$, Robert M. Kalin $1, * \mathbb{C}$, Ibrahim Hassan ${ }^{1,3} \oplus$, Philippe Sentenac ${ }^{1}$ \\ and Moshood N. Tijani ${ }^{2}$ \\ 1 Department of Civil and Environmental Engineering, University of Strathclyde, Glasgow G1 1XJ, UK; \\ ibrahim.hassan@strath.ac.uk (I.H.); Philippe.sentenac@strath.ac.uk (P.S.) \\ 2 Department of Geology, University of Ibadan, Ibadan 200284, Nigeria; mn.tijani@mail.ui.edu.ng \\ 3 Department of Civil Engineering, Abubakar Tafawa Balewa University, Bauchi 740272, Nigeria \\ * Correspondence: jamiu.aladejana@strath.ac.uk (J.A.A.); Robert.Kalin@Strath.ac.uk (R.M.K.); \\ Tel.: +44-7717-651-171 (J.A.A.)
}

Received: 20 July 2020; Accepted: 6 November 2020; Published: 10 November 2020

\begin{abstract}
This study employed stable isotopes of $\delta^{18} \mathrm{O}$ and $\delta^{2} \mathrm{H}$ in conjunction with other hydrological parameters to understand the origin, inferred residence time, and seasonal effect of groundwater in the shallow aquifers of the eastern Dahomey Basin. A total of 230 groundwater samples ( 97 in the wet season and 133 in the dry season) were collected from the borehole and shallow aquifer between May 2017 and April 2018. Groundwater analysis included major ions and $\delta^{18} \mathrm{O}$ and $\delta^{2} \mathrm{H}$, isotopes data in precipitation from three selected Global Network of Isotope in Precipitation (GNIP) stations across West Africa, Douala in Cameroon, Cotonou in Republic of Benin, and Kano in Nigeria were used in comparative analysis. Results of the hydrochemical model revealed $\mathrm{Ca}-\mathrm{HCO}_{3}$ and $\mathrm{Na}-\mathrm{Cl}$ as dominant water types with other mixing water types such as $\mathrm{Ca}-\mathrm{SO}_{4}, \mathrm{Ca}-\mathrm{Cl}, \mathrm{Na}-\mathrm{SO}_{4}$, and $\mathrm{K}-\mathrm{Mg}-\mathrm{HCO}_{3}$, which characterised early stage of groundwater transformation as it infiltrates through vadose zone into the aquifer. $\delta^{18} \mathrm{O}$ and $\delta^{2} \mathrm{H}$ precipitation data from the three stations plotted along with the groundwater samples indicate recent meteoric water origin, with little effect of evaporation during the dry season. The plot of Total Dissolved Solids (TDS) against $\delta^{18} \mathrm{O}$ showed clustering of the water samples between the recharge and the evaporation zone with dry season samples trending towards increased TDS, which is an indication of the subtle effect of evaporation during this period. Tracing groundwater types along the flow paths within the basin is problematic and attributed to the heterogeneity of the aquifer with anthropogenic influences. Moreover, a comparison of the $\delta^{18} \mathrm{O}$ and $\delta^{2} \mathrm{H}$ isotopic compositions of groundwater and precipitation in the three selected stations, with their respective deuterium excess (D-excess) values established low evapotranspiration induced isotope enrichment, which could be due to higher precipitation and humidity in the region resulting in low isotope fractionation; hence, little effect of seasonal variations. The study, therefore, suggested groundwater recharge in the shallow aquifer in the eastern Dahomey Basin is of meteoric origin with a short residence time of water flows from soils through the vadose zone to the aquifers.
\end{abstract}

Keywords: hydrogen and oxygen isotopes; groundwater sources; residence time

\section{Introduction}

Rock-water interaction is a process that influences groundwater chemical evolution from recharge along the flow paths through the vadose zone to the phreatic zones. Aquifers' mineral solubility, residence time, and intrinsic chemical characteristics of original water determine how quickly 
groundwater quality changes [1,2]. The origin of water also plays a role before continuous evolution as it flows from the recharge zone downgradient within the geological unit of formations [3]. Sedimentary basins play a vital role as sources of water supply to meet water demand, especially in developing countries in Africa and Asia. Sub-Saharan African countries depend mostly on groundwater to meet their daily water demand due to infrastructural failure and poor water management [4,5]. Generally, groundwater resources are under stress from natural and human drivers. Coastal basins are more susceptible to these pressures due to their proximity to the sea, increased population, industrialisation, agricultural activities and the effect of global climate change [6,7]. For coastal basins, the stratigraphical characteristics make aquifers vulnerable to contamination and pollution [8]. Shallow coastal aquifers in some developing countries have been reported to be facing various challenges of groundwater quality deterioration, the causes of which are attributed to both geogenic and anthropogenic influence.

Delineation of the hydrochemical status is usually a complicated and multi-source process. This is a common challenge in hydrological basins characterised with municipal, agricultural, and industrial activities. The activities associated with these areas often serve as a source of non-geogenic ions in groundwater [9]. These anthropogenic ions and metals influence the hydrochemical characteristics of groundwater. However, the geogenic processes such as saltwater intrusion, sea spray, and minerals dissolution from rock-water interaction remain the primary source of ions and metals in groundwater [1, $10,11]$. In the near-ocean areas of coastal basins, $\mathrm{Na}-\mathrm{Cl}$ is commonly the dominant water type, which is attributed to sea spray or seawater intrusion. In light of this, mineral dissolution and hydrochemical evolution of groundwater can be better understood using stable isotopes in conjunction with major ions. These will provide an insight into the hydrochemical transformation and residence time of groundwater within aquifers of such coastal basin [12-14].

Stable isotopes integrated with major ions in groundwater have been employed in regional groundwater studies at different locations across the world. The works of [2,15-20] have demonstrated effectiveness of this approach in understanding recharge pattern, origin and residence time of groundwater from specific sites to basin-scale hydrogeological investigations. Most of these studies have contributed vital information and knowledge that are useful in global groundwater resource management.

The eastern Dahomey Basin (EDB) is one of the eight hydrogeological provinces of Nigeria, providing groundwater demand for about 30\% of the country's population. Urbanisation, industrialisation, and agriculture, coupled with the dynamic geology of this basin, continue to pose a significant challenge to the understanding of its groundwater chemical dynamics [21,22]. In Nigeria, inadequate pipe-borne water leaves individual households to rely on groundwater from shallow boreholes and hand-dug wells to meet water demand for domestic, agriculture, and other usages $[23,24]$. A unique characteristic of this basin is its complex geology and relief with a drainage system controlled by topography and geology [8]. Most of the major rivers in the basin flow southward across different geologic units and formations and discharge water into lagoons and the ocean. During the process of groundwater flow from the recharge area at the northern parts (upslope) of the Basin to recharge major rivers through baseflow or recharging the aquifers, the water interacts with aquifer materials which alter the chemistry of the water.

Most of the hydrogeologic studies in the eastern Dahomey Basin are fragmented, primarily focusing on specific sites and locations, with few including stable isotopes. Using a stable isotope method that cut across the entire EDB is necessary to advance the current understanding of its regional hydrogeological system. Groundwater originates from local atmospheric precipitation $[25,26]$, and seasonal effect and variations in precipitation are dampened during infiltration, mixing and isotope effects $[27,28]$. Although, some seasonal variations may exist depending on the hydrological properties, size and thickness of the vadose zone $[20,25]$. These variations may cause distinctions in isotopic compositions of groundwater from precipitation recharge to discharge. The phenomenon that usually results from selective recharge or isotopic fractionation effects associated with evapotranspiration and runoff $[1,29]$. 
Understanding the hydrochemical dynamics at a regional level is critical in the development of a sustainable water resource management regulation [30]. As part of understanding the hydrogeochemical dynamics of shallow coastal aquifers of the eastern Dahomey Basin (EDB), this study aimed to apply stable environmental isotopes of $\delta^{18} \mathrm{O}$ and $\delta^{2} \mathrm{D}$ in combination with key hydrochemical parameters for a conceptual model of how groundwater chemistry changes across different geological units and formation within the EDB. This model adds to the knowledge required by water professionals and policymakers to develop an effective strategy for water resources management and protection for this extensive aquifer.

\subsection{Study Area}

The eastern Dahomey Basin is administratively located in the South-Western part of Nigeria. It is bordered to the west, east and north by the Republic of Benin, Okitipupa Ridge, and the Precambrian Basement Rocks, respectively, while stretching south into the Atlantic Ocean. Geographically, the EDB is located between Latitudes $2^{\circ} 41^{\prime} 10^{\prime \prime}$ and $4^{\circ} 59^{\prime} 59^{\prime \prime} \mathrm{N}$ and Longitudes $6^{\circ} 21^{\prime} 13^{\prime \prime}$ and $7^{\circ} 52^{\prime} 42^{\prime \prime} \mathrm{E}$ along the coast of the Gulf of Guinea (Figure 1). The Nigerian part of this basin is known as the eastern Dahomey Basin which underlies the three states of Lagos, Ogun, and Ondo. The study area is low lying, with several points virtually at or below sea level, which is always saturated with water, and prone to flooding. The highest elevation, $265 \mathrm{~m}$ above sea level, is at Abeokuta town, where the basin thins out into the Precambrian basement rocks [21]. The climate of the basin is characterised by wet and dry seasons, within the tropical rain forest belt. Precipitation in this area occurs as rainfall and ranges between 750 and $1000 \mathrm{~mm}$ (Figure 1) mostly between April and October (wet season) and $250 \mathrm{~mm}$ and $500 \mathrm{~mm}$ between November and March (dry season) [31].

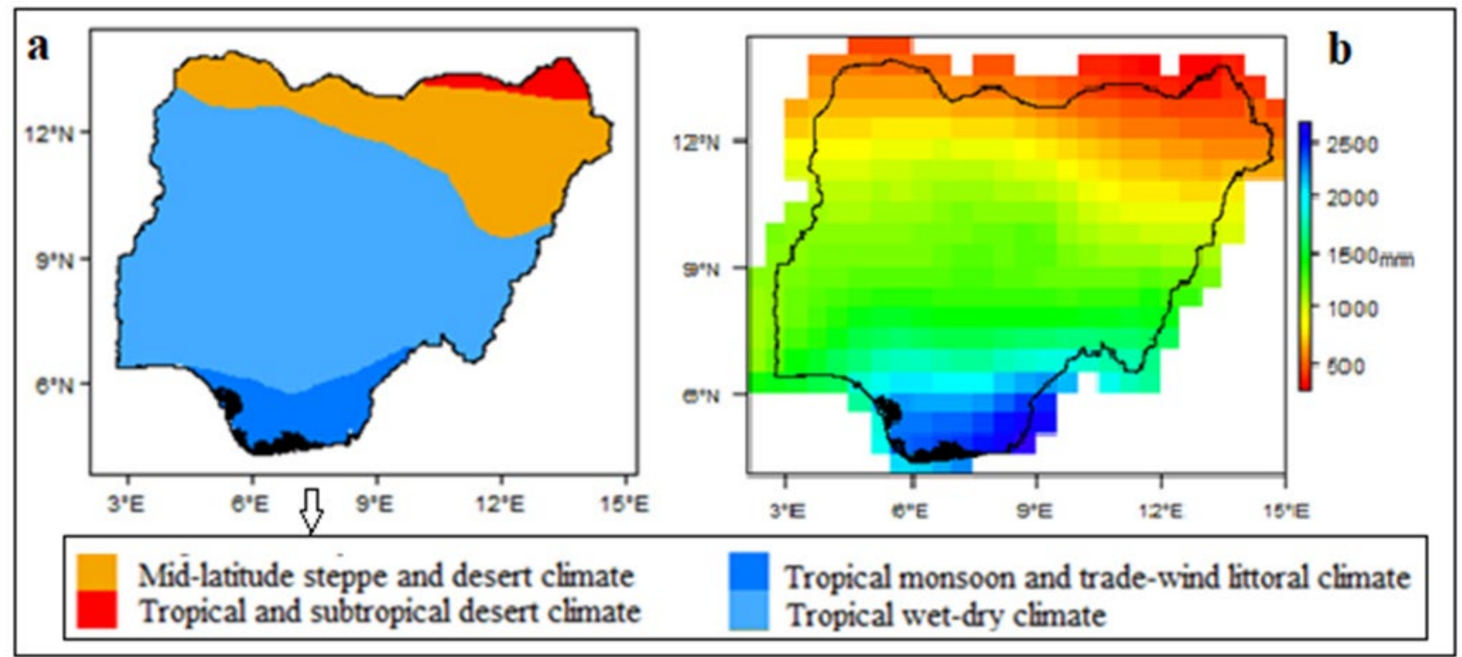

Figure 1. Spatial distribution maps of (a) climate zones in Nigeria, (b) rainfall across Nigeria (adapted from [32]).

\subsection{Geology and Hydrogeology}

\subsubsection{Geology}

The area is a part of the Dahomey Basin which extends from Nigeria to Ghana. The lithological character of the sediments is a result of transgressions and regressions of the sea since the Cretaceous age, the transgressions coming from the south. The stratigraphic description of the sediments has been provided by various authors, including [31,33-35] as presented in Figure 2. The Coastal Plain Sands (recent-Oligocene) constitute the main aquifer of the area which is exploited through hand-dug wells and boreholes. It forms a multi-aquifer system consisting of three aquifer horizons separated by clayey layers [31,36]. Quaternary alluvial sediments cover most of the Lagos coastal areas and river valleys. 


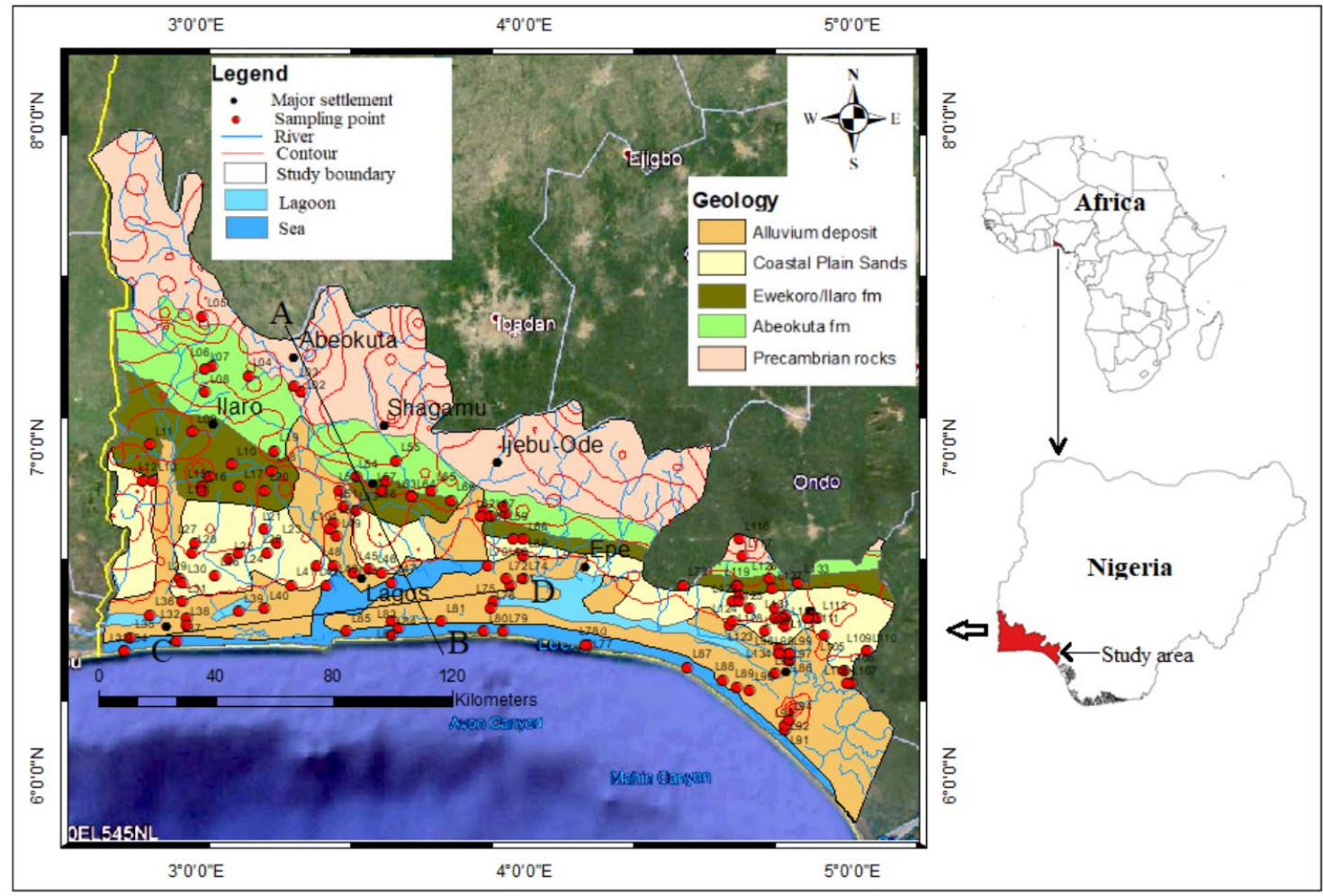

Figure 2. Map of the study area showing sampling points, contour line, rivers and geology.

\subsubsection{Hydrogeology}

The hydrostratigraphy of the study area has been explained by several researchers $[8,31,37-42]$. Depth to the aquifer units varies across the basin. The depth ranges from 5-23 $\mathrm{m}$ for the primary unconfined aquifer while depth to three confined aquifers are in the range of 7-80 m, 63-188 m, and 245-261 m, respectively (Figure 3). The respective thicknesses of these aquifers range from 7-26 m, 6-67 m, 20-143 m, and 61-117 m. The description of these aquifers is presented in stratigraphical sections along profiles $\mathrm{AB}$ and $\mathrm{CD}$, as shown in Figure 3. The aquifers are bounded by intercalation of shale, tar sands, and layers of sandy clay with relatively low hydraulic conductivity. Two main aquifer units were identified within the Upper Coal Measures. The depths to the top/thicknesses of the aquifer units are $9.8 \mathrm{~m}(1.7 \mathrm{~m})$ and $23 \mathrm{~m}(5.3 \mathrm{~m})$, respectively. The Nkporo Shale had a thickness and depth to the top of the only identified aquifer unit as $10 \mathrm{~m}$ and $16 \mathrm{~m}$, respectively [39]. At the northern parts of the study area, the sedimentary rocks of the Abeokuta formation thin-out on the Precambrian basement rocks. Most of the wells and boreholes in this area are drilled through the upper sandy layers into the weathered profile of the Precambrian basement rocks tapping water through weathered overburden, and sometimes fractured basement rocks, depending on locations and the weathering status. The regional groundwater flow direction across the basin is north-south as shown in Figure 3 . Though, local groundwater flow direction is north-east and east-west as it recharges the tributaries to major rivers (River Ogun, Oluwa, and Ose) as baseflow. These rivers flow approximately southward and ended up in the ocean (Figure 2). 


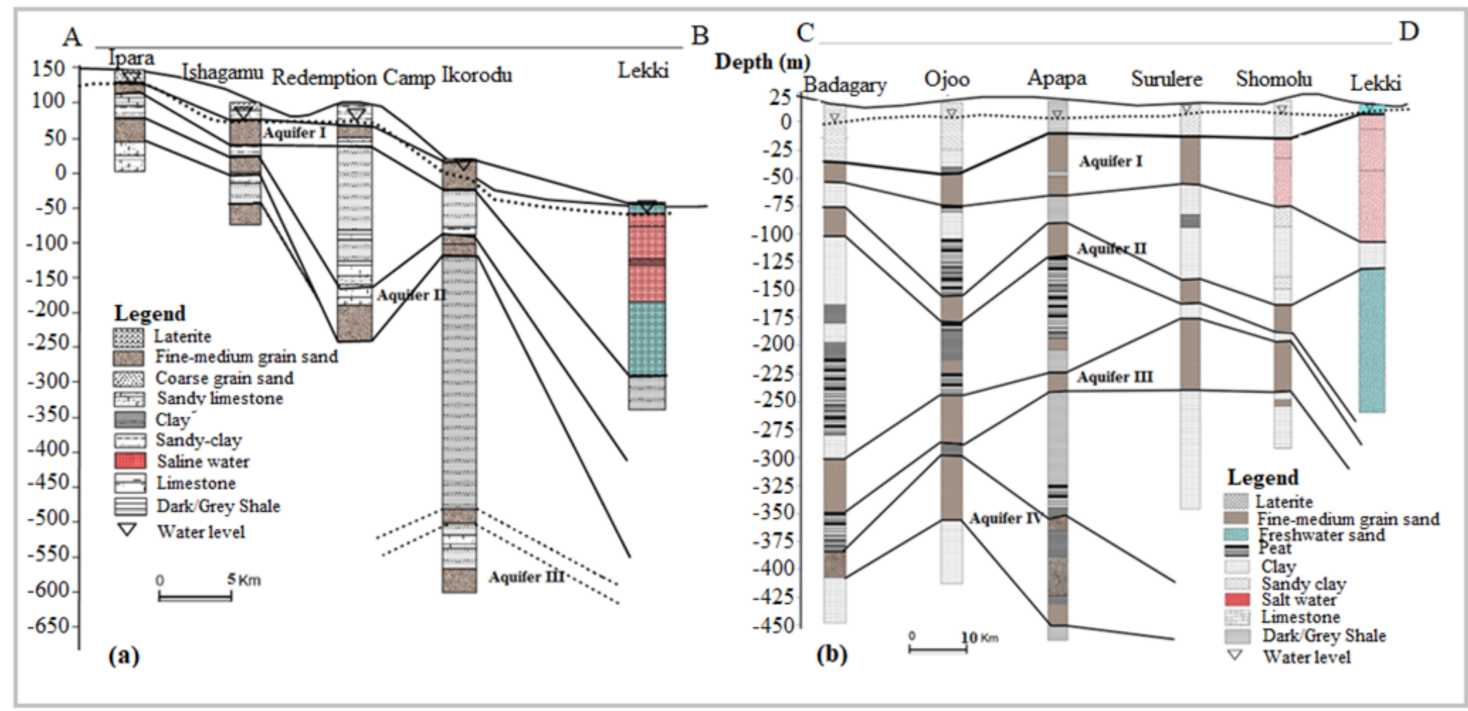

Figure 3. Hydrostratigraphic section across: (a) profile line $A B$ and (b) profile line $C D$, showing different aquifer layers in part of the study area.

\section{Materials and Methods}

\subsection{Field Physicochemical Measurement}

Well-inventories were carried out on a total number of 230 shallow hand-dug wells, shallow tube wells, and boreholes from the eastern Dahomey Basin (EDB), 96 in the wet season, and 134 in the dry season between May 2017 and April 2018. The physicochemical parameters were measured in the field using a Teckoplus 6-in-1 pen-type water quality tester Model $99720 \mathrm{pH} /$ conductivity meter capable of measuring total dissolved solids (TDS), salinity, temperature, and redox potential (Eh/ORP). The depth of the wells and static water level was measured with the aid of a water depth meter while the coordinates of each sampled well were recorded using Global Positioning System (GPS). The 230 groundwater samples were collected in three separate sets of $50 \mathrm{ml}$ polypropylene tubes labelled A, $\mathrm{B}$, and IS. Samples labelled A were acidified to a $\mathrm{pH}<2$ after collection with $0.4 \mathrm{ml}$ of concentrated nitric acid $\left(\mathrm{HNO}_{3}\right)$. Samples B and IS were filtered with a $0.45 \mu \mathrm{m}$ filter and preserved in an ice-packed cooler to keep the samples' temperature below $4{ }^{\circ} \mathrm{C}$ before being transported to the laboratory for further analysis.

\subsection{Laboratory Analysis}

(a) Major ions and trace metals analysis: three sets of water samples were analysed. Samples labelled (A) were prepared by collecting $10 \mathrm{ml}$ of each sample in a centrifuge polyethylene tube and arranged serially for Inductively Coupled Plasma (ICP-MS) analysis of cations. The same arrangement was used for the sample set labelled (B) for Ion Chromatography (IC) for the anions analysis in the Environmental Laboratory, Department of Civil and Environmental Engineering, University of Strathclyde. Alkalinity (HCO3-) was determined using a Digital Titrator (Model: 16900, HACH International, Loveland, CO, USA) and 1.6 N H2SO4 cartridge.

(b) Stable isotopes analysis in groundwater: samples labelled (IS) were shipped to the Ministry of Agriculture, Irrigation and Water Development Isotope Laboratory, Blantyre, Malawi under a temperature below $4{ }^{\circ} \mathrm{C}$ for the stable isotope of $\delta^{2} \mathrm{H}$ and $\delta^{18} \mathrm{O}$ analysis. The analysis of groundwater samples was carried out following the same method of isotope water samples as described in [18] and laboratory analysis was conducted in line with International Standard Procedures with appropriate quantification and validation of results. 


\subsection{Regional Precipitation Data}

Regional precipitation isotope data was needed for this study to identify any possible deviation from the Global Meteoric Water Line (GMWL) to characterise local meteoric conditions better. The closest Global Network of Isotope in Precipitation (GNIP) data stations to the study location in the eastern Dahomey Basin are Cotonou (Republic of Benin) to the west and Douala (Cameroon) to the east. The only station in Nigeria is situated in Kano, at the northern savannah region of Nigeria. Meanwhile, Cotonou, and Douala, located along the coast of West Africa, share similar climate conditions with the study area (Figure 4). In light of this, a total of 134 regional and annual precipitation isotope data of $\delta^{18} \mathrm{O}$ and $\delta^{2} \mathrm{H}$ were collected from the Douala, Cameroon (50), Cotonou, Republic of Benin (50) and Kano, Nigeria (33) meteorological stations during 2009-2018. These isotope data were downloaded from the GNIP and are presented later in this study. The results are expressed as $\delta$-values relative to V-SMOW (Vienna Standard Mean Ocean Water), and the measurement precision is $0.01 \%$ o and $0.2 \%$ o for $\delta^{18} \mathrm{O}$ and $\delta^{2} \mathrm{H}$, respectively.

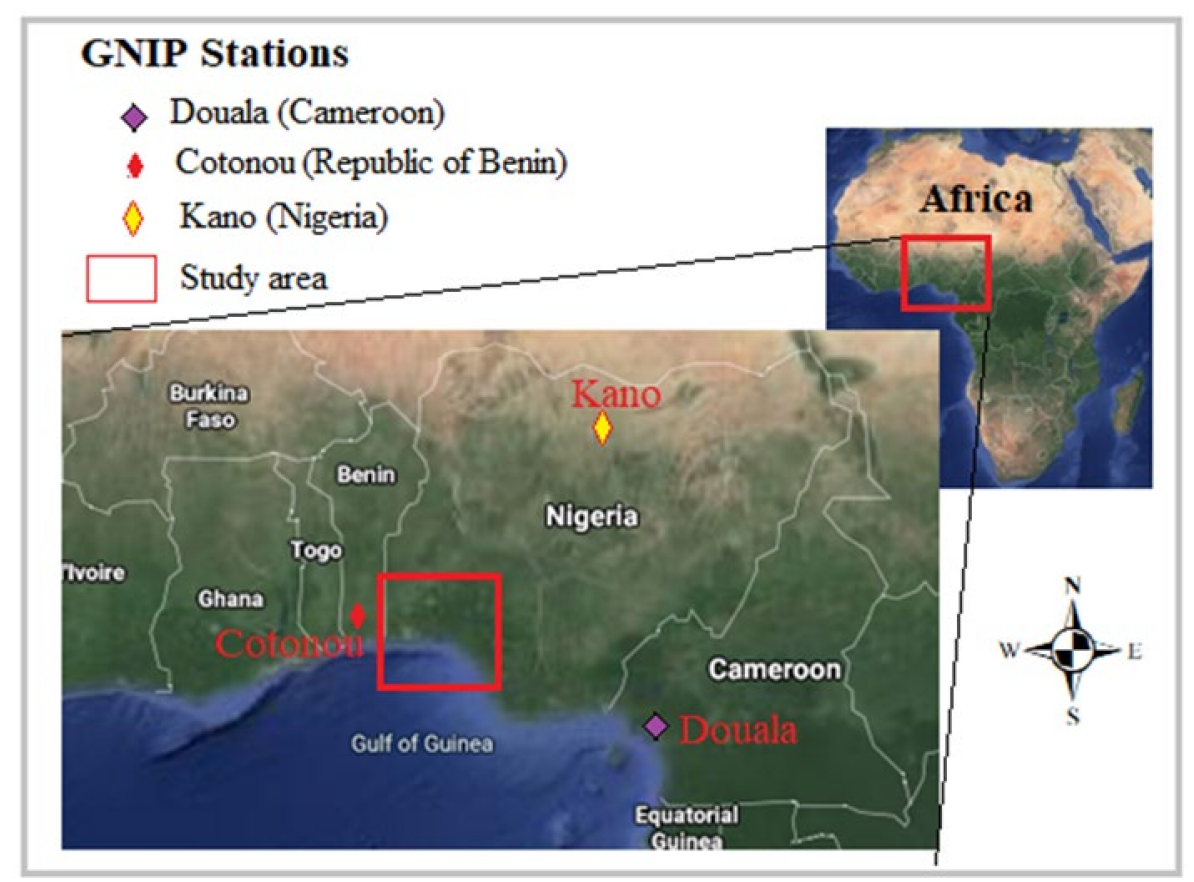

Figure 4. Map showing the regional Global Network of Isotope in Precipitation (GNIP) stations within West Africa (adapted from Google Earth Pro).

\subsection{Data Analysis and Evaluation}

Data from the field and laboratory measurements were checked for quality by correlating selected major ions from randomly duplicated samples, of which the correlation values are all above 0.9 , indicating low to insignificant analytical errors. Total dissolved solids (TDS), $\mathrm{pH}$, electrical conductivity (EC) temperature and major ions were analysed using Geochemist Workbench to determine groundwater types for the study area. Piper diagrams for both seasons were also plotted using the same software. Results of water types were used in relation to the major ions for other plots in Excel. At the same time, the spatial distribution maps of the stable isotopes were generated in ArcGIS v10.6.

\section{Results and Discussion}

The result of the physicochemical parameters and stable isotopes are presented in Table 1 . The $\mathrm{pH}$ of groundwater samples during the wet and dry season range from 4.0 to 8.1 (average of 5.6) and 3.9 to 8.0 (average of 7) respectively. The $\mathrm{pH}$ of groundwater is slightly higher in the wet season compared to 
the dry season. TDS ranged from 0.0 to $8500 \mathrm{mg} / \mathrm{l}$ (average of 201.8) and 2.3 to $6750 \mathrm{mg} / \mathrm{l}$ (average of $236 \mathrm{mg} / \mathrm{l}$ ) while EC ranges from 0.0 to $12000 \mu \mathrm{S} / \mathrm{cm}$ (average of $295.4 \mu \mathrm{S} / \mathrm{cm}$ ) and 5.5 to 10,009 $\mu \mathrm{S} / \mathrm{cm}$ (average of 352.4) for wet and dry seasons respectively. The temperature of groundwater ranged from 25.5 to $34.6^{\circ} \mathrm{C}$ (average of $39.4{ }^{\circ} \mathrm{C}$ ) and 26.6 to $37.7^{\circ} \mathrm{C}$ (average of $31.2^{\circ} \mathrm{C}$ ) during wet and dry seasons, respectively.

Table 1. Statistical summary of physicochemical parameters and stable isotopes in groundwater.

\begin{tabular}{ccccccccc}
\hline \multirow{2}{*}{ Parameter } & \multicolumn{4}{c}{ Wet Season } & \multicolumn{5}{c}{ Dry Season } \\
\cline { 2 - 9 } & Min & Max & Aver & Std Dev & Min & Max & Aver & Std Dev \\
\hline $\mathrm{Ca}^{2+}$ & 0.3 & 374.0 & 16.5 & 41.2 & 0.2 & 448.5 & 21.6 & 55.2 \\
$\mathrm{Mg}^{2+}$ & 0.0 & 1377.0 & 18.4 & 140.4 & 0.1 & 1125.0 & 16.1 & 102.2 \\
$\mathrm{Na}^{+}$ & 0.1 & 8857.0 & 106.8 & 902.8 & 0.6 & $10,310.0$ & 112.7 & 907.4 \\
$\mathrm{~K}^{+}$ & 0.1 & 447.1 & 10.5 & 46.2 & 0.1 & 590.2 & 10.1 & 51.6 \\
$\mathrm{HCO}_{3}^{-}$ & 1.0 & 028.5 & 142.3 & 818.7 & 1.6 & 8390.0 & 139.5 & 767.6 \\
$\mathrm{SO}_{4}^{2+}$ & 0.0 & $2,210.7$ & 37.0 & 242.2 & 0.3 & 2932.0 & 39.7 & 259.8 \\
$\mathrm{Cl}^{-}$ & 0.1 & $18,970.2$ & 218.1 & $1,934.3$ & 0.9 & $18,833.0$ & 206.3 & 1677.6 \\
$\mathrm{NO}_{3}^{-}$ & 0.0 & 258.6 & 31.8 & 54.1 & 0.3 & 311.9 & 30.1 & 54.3 \\
$\mathrm{pH}$ & 4.0 & 8.1 & 5.6 & 1.0 & 3.9 & 8.0 & 5.6 & 1.9 \\
$\mathrm{TDS}$ & 0.0 & 8500.0 & 201.8 & 863.6 & 2.3 & 6750.0 & 235.8 & 672.7 \\
$\mathrm{EC}$ & 0.0 & $12,000.0$ & 295.4 & 1219.4 & 5.5 & $10,009.0$ & 352.4 & 1002.0 \\
$\mathrm{Temp}$ & 25.5 & 34.6 & 29.4 & 1.7 & 26.6 & 99.9 & 60.1 & 28.9 \\
$\delta^{2} \mathrm{H}(\%)$ & -32.5 & 2.3 & -13.1 & 3.6 & -19.7 & 7.5 & -12.4 & 2.8 \\
$\delta^{18} \mathrm{O}(\%)$ & -5.2 & 0.3 & -3.0 & 0.6 & -4.0 & 0.8 & -3.0 & 0.5 \\
$\mathrm{D}-\mathrm{excess}$ & -0.3 & 13.8 & 11.0 & 1.7 & 0.9 & 15.0 & 11.9 & 1.6 \\
\hline
\end{tabular}

Major ions and Total Dissolved Solids (TDS) are measured in $\mathrm{mg} / \mathrm{l}$, electrical conductivity (EC) in $\mu \mathrm{S} / \mathrm{cm}$ and temperature in ${ }^{\circ} \mathrm{C}$.

\subsection{Hydrochemical Characterisation}

Analysis of hydrochemical data using Geochemist's Work Bench revealed eight hydrochemical water types, $\mathrm{Ca}-\mathrm{HCO}_{3}, \mathrm{Na}-\mathrm{Cl}, \mathrm{Na}-\mathrm{HCO}_{3}, \mathrm{Ca}-\mathrm{Cl}, \mathrm{B} \mathrm{Na}-\mathrm{SO}_{4}, \mathrm{Ca}-\mathrm{SO}_{4}, \mathrm{~K}-\mathrm{Cl}$ and $\mathrm{Mg}-\mathrm{SO}_{4}$ across the geologic units of the basin as presented in Figure 5 and supported by the piper diagrams (Figure 6). $\mathrm{Na}-\mathrm{Ca}$ and $\mathrm{Ca}-\mathrm{HCO}_{3}$ water types are the dominant water type among the groundwater samples from the shallow aquifer of the basin. The groundwater types (Figure 5) along the flow paths within the basin provide clues to the prevailing hydrochemical processes of mixing as large portion of samples clustering in the mixing region of the piper diagram (Figure 6), especially in the wet season. Figures 7 and 8 present pie charts of water type across the geological units to possibly link the prevailing groundwater characteristics in each of the aquifers mineralogy as it plays a vital role in this regard.

As these water types reflect the mineralogical composition of the basin sediment and rocks, there is no observed consistency in their pattern of distribution across the geologic units of the study basin. The lack of a defined distribution pattern could be attributed to the heterogeneous nature of any typical sedimentary basin. 


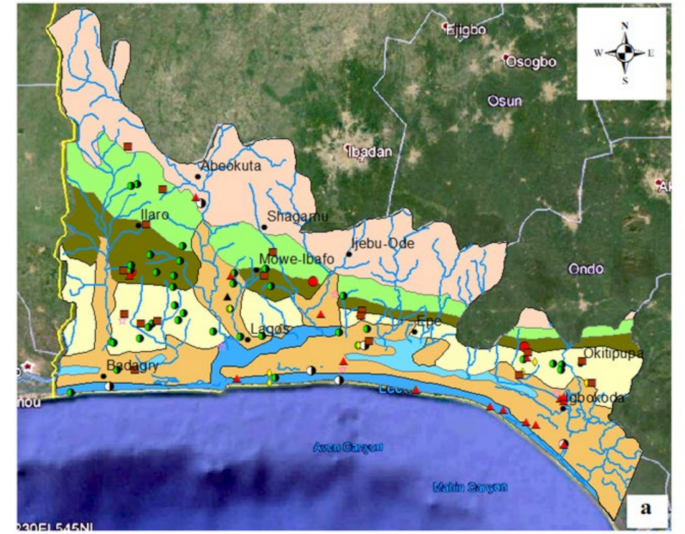

\section{Groundwater}

- $\mathrm{Ca}-\mathrm{Cl}$

- $\mathrm{Ca}-\mathrm{HCO}_{3}$

- $\mathrm{Ca}-\mathrm{SO}_{4}$

- ${ }^{\mathrm{Na}-\mathrm{SO}_{4}}$

- $\mathrm{Na}-\mathrm{Cl}$

* $\mathrm{Mg}-\mathrm{HCO}_{3}$

- $\mathrm{K}-\mathrm{SO}_{4}$

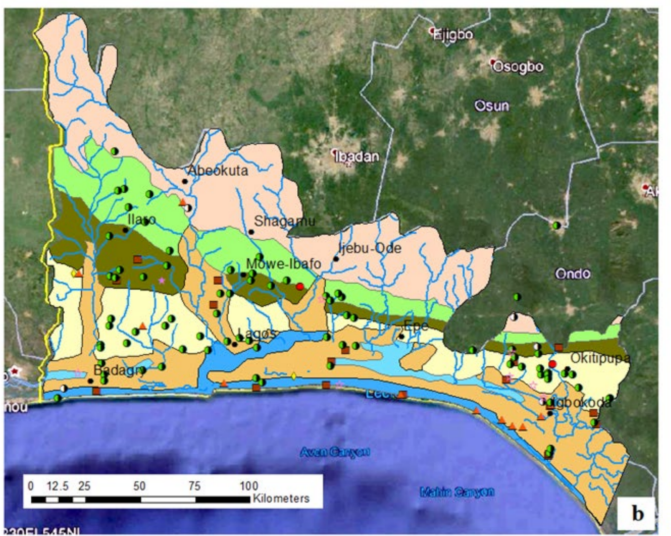

Legend

- River

$\square$ Study boundary

$\square$ Lagoor
Sea

Geology

$\square$ Alluvium deposit

Coastal Plain Sands

Abeokuta fm

$\square$ Precambrian rocks

Figure 5. Spatial distribution of groundwater types across a different geological unit of the eastern Dahomey Basin, (a) wet season, (b) dry season.

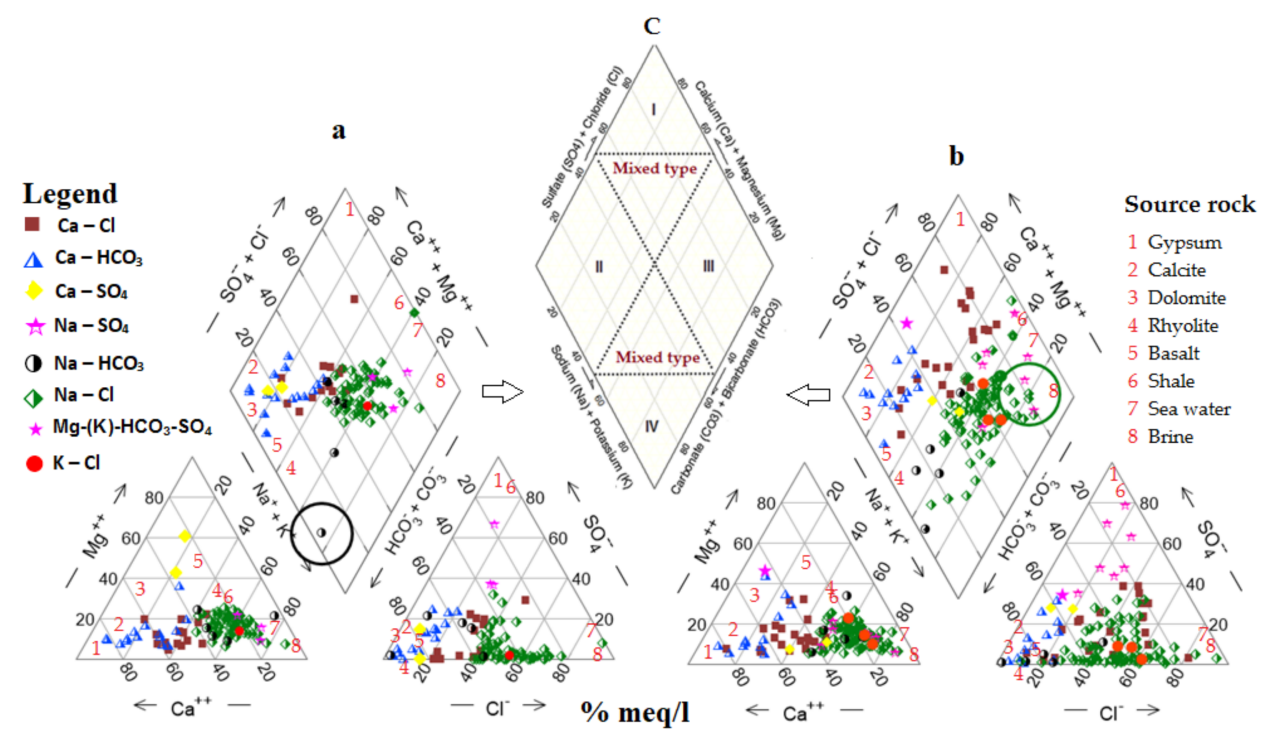

Figure 6. Piper diagram showing water types: (a) wet season groundwater samples; (b) dry season groundwater samples; (c) diamond chart for interpretation indicating mixed water types and ( $\mathrm{I}=$ permanent hardness, $\mathrm{II}=$ temporary hardness, $\mathrm{III}=$ saline and IV = alkali carbonate). 


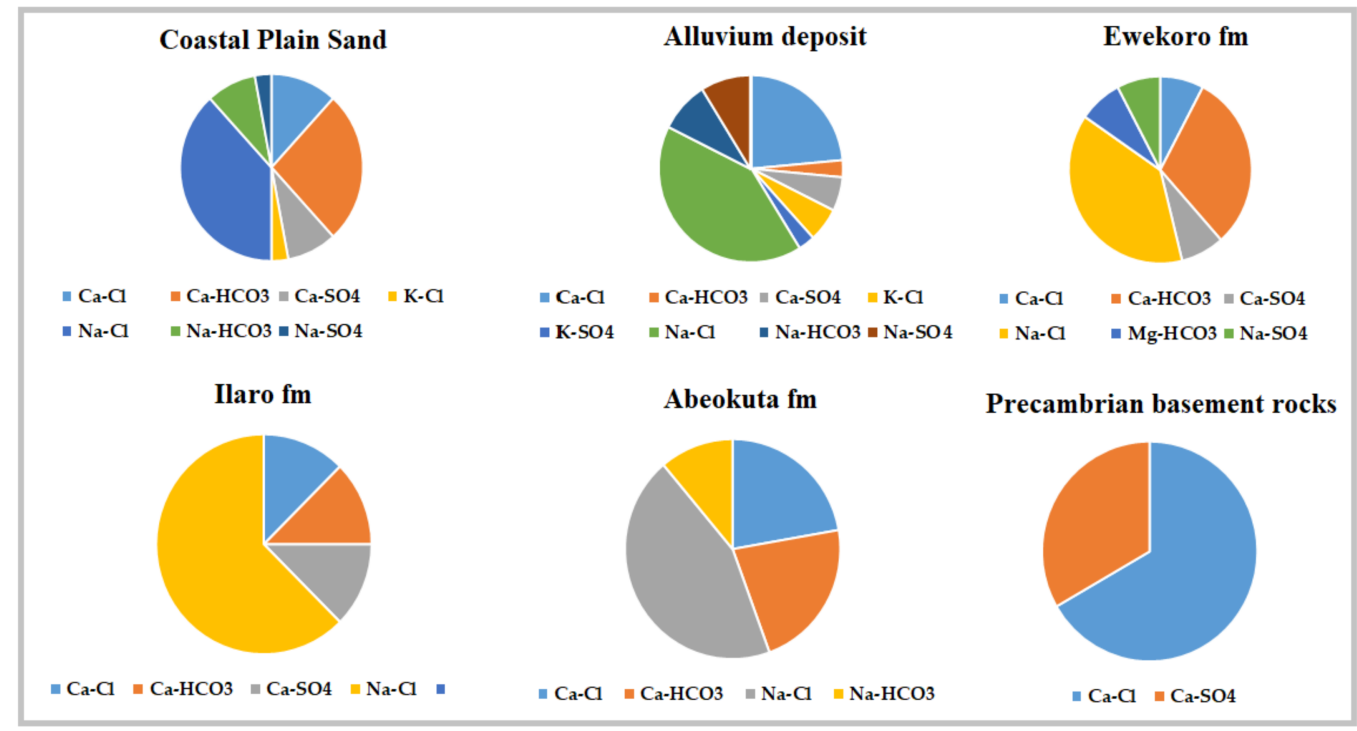

Figure 7. Pie chart of percentage water type across the geologic units within the basin for the wet season water samples.

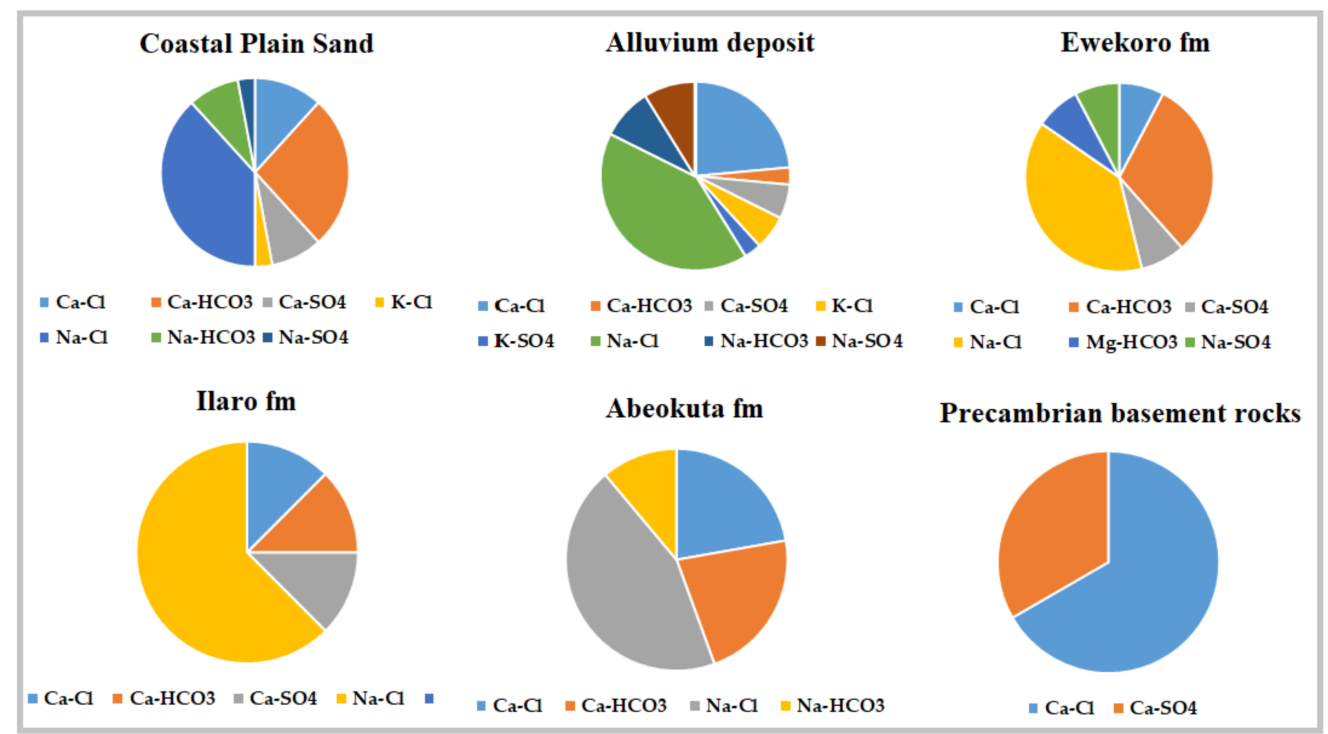

Figure 8. Pie chart of percentage water type across the geologic units within the basin for the dry season water samples.

The hydrochemical process is complex and dynamic depending on many factors, ranging from the groundwater origin rock/minerals weathering status and mineral composition of the aquifer $[9,20]$. The residence time between precipitation and aquifer recharge zones and impact from humans along the flow paths are compounding factors [19]. Meteoric water is generally dominated by $\mathrm{Ca}-\mathrm{HCO}_{3}$ or $\mathrm{Ca}-\mathrm{Mg}-\mathrm{HCO}_{3}$ water types, [29], with $\mathrm{Na}^{+}$and $\mathrm{K}^{+}$additions when water interacts with rock-forming minerals, as shown in Equations (1) and (2).

Equation (1).

$$
\mathrm{KAlSi}_{3} \mathrm{O}_{8}+\mathrm{H}_{2} \mathrm{CO}_{3}+\mathrm{H}_{2} \mathrm{O} \rightarrow \mathrm{Al}_{2} \mathrm{Si}_{2} \mathrm{O}_{5}(\mathrm{OH})_{4}+2 \mathrm{~K}^{+}+4 \mathrm{H}_{4} \mathrm{SiO}_{4}+\mathrm{HCO}_{3}^{-}
$$

Equation (2).

$$
2 \mathrm{NaAlSi}_{3} \mathrm{O}_{8}+2 \mathrm{H}_{2} \mathrm{CO}_{3}+2 \mathrm{H}_{2} \mathrm{O} \rightarrow \mathrm{Al}_{2} \mathrm{Si}_{2} \mathrm{O}_{5}(\mathrm{OH})_{4}+2 \mathrm{Na}^{+}+4 \mathrm{SiO}_{4}+2 \mathrm{HCO}_{3}^{-}+\mathrm{H}_{2} \mathrm{O}
$$


The precipitation/infiltration water carries dissolved gases as it recharges, resulting in a weak acid of mainly carbonic with minor nitric or sulphuric acids (depending on anthropogenic pollution). Hydrolysis, acidolysis, and oxidation processes take place as aquifers are recharged through the infiltration of water into soils of the vadose zones [43-45]. Towards the northern part of the eastern Dahomey Basin, the Precambrian basement rocks are often characterised with highly weathered overburden, which outcropped in few locations around road cuts and mine sites. The weathered overburden exposures were documented (Figure 9) during field mapping and sampling, which show impression of transformed feldspar to kaolinite through the weathering process, as explained in Equations (1) and (2) above. The thick saprolite layer of this profile is highly rich in secondary clay mineral such as kaolinite (Figure 9) as confirmed in the work of [46]. This could be the possible source of geogenic ions such as $\mathrm{Ca}, \mathrm{Na}$, and $\mathrm{K}$ found in groundwater from recharge zones of the basin (Figure 5) and responsible for $\mathrm{Ca}, \mathrm{Na}$, and $\mathrm{K}$ bicarbonate/sulphate water types observed in this study.

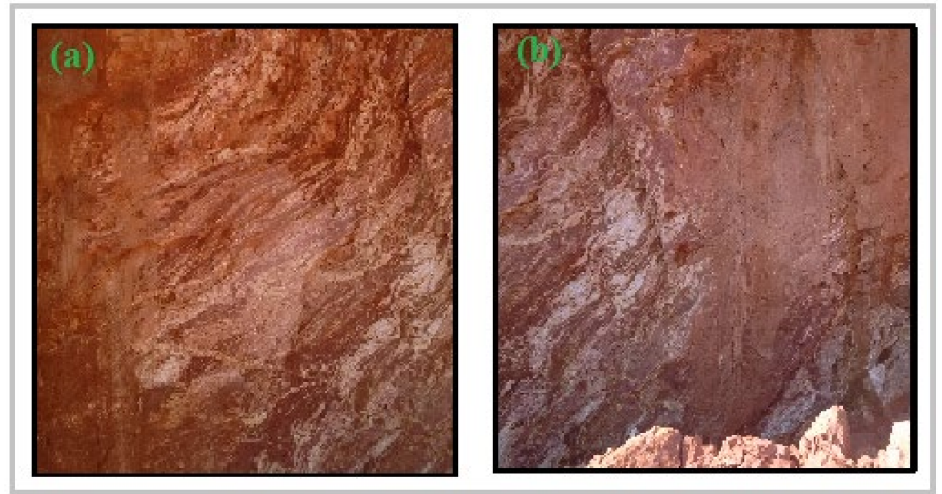

Figure 9. Weathering profile of Precambrian basement rocks underlying the oldest Abeokuta formation. (At the northern boundary of the basin from which aquifer recharge of the basin originates (a) road cut along Abiola Way, Abeokuta, (b) a road cut along ljebu-Remo and Agowoye road. The weathered profile is known for its richness in kaolinite minerals).

\subsection{Oxygen and Deuterium Isotopes of Groundwater of EDB}

Information on precipitation, evaporation and origin of water can be deduced from the stable isotopes of oxygen $\left(\delta^{18} \mathrm{O}\right)$ and hydrogen $\left(\delta^{2} \mathrm{H}\right)$ values $[2,47,48]$. The relationship between $\delta^{2} \mathrm{H}$ and $\delta^{18} \mathrm{O}$ data is usually plotted in relation to the Global Meteoric Water Line (GMWL) defined by the equation: $\delta^{2} \mathrm{H}=8 \delta^{18} \mathrm{O}+10[20,28]$. Stable isotopes of $\delta^{18} \mathrm{O}$ and $\delta^{2} \mathrm{H}$ have been used to understand the origin of groundwater in the eastern Dahomey Basin and suggested recent groundwater from precipitation [49]. In this study, $\delta^{18} \mathrm{O}$ and $\delta^{2} \mathrm{H}$ were used to explain the hydrochemical evolution of water as it flows from the surface as precipitation and infiltrates into the soil through the vadose zone to the aquifers. Results from isotopes data of groundwater samples during the wet and dry season show $\delta^{18} \mathrm{O}$ values range from -5.2 to $0.3 \%$ ond -4 to $0.8 \%$ with an average value of $-3 \%$, respectively, for both wet and dry seasons (Table 1 ). $\delta^{2} \mathrm{H}$ values range from -32 to $2.3 \%$ ond -19 to $7.5 \%$ o with an average value of -13.1 and $-12.4 \%$ o (Table 1 ), respectively, for wet and dry seasons. In this study, the $\delta \mathrm{D} / \delta^{18} \mathrm{O}$ diagrams (Figure 10) show that the groundwater for both seasons plotted along a line of lower slope slightly deviated from the Global Meteoric Water Line (GMWL) is indicative of evaporation. This implies recent water from precipitation with a slight influence of evaporation [13,49]. A higher evaporation influence is observed in the dry season groundwater samples with lower slope and deuterium intercept values of 5.5 and 4.1 compared to those of wet season with values of 6.1 and 5.2, respectively, as presented in Figure 10. Figures 11 and 12 show the spatial distribution of $\delta^{18} \mathrm{O}$ and $\delta \mathrm{D}$ for wet and dry seasons, respectively. 


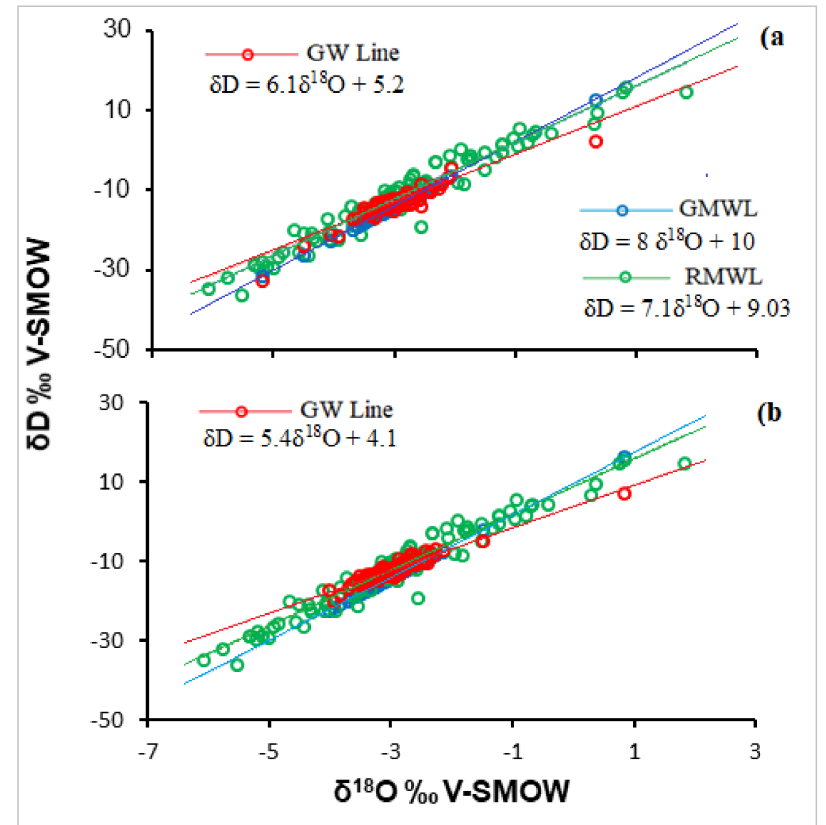

Figure 10. $\delta \mathrm{D} / \delta^{18} \mathrm{O}$ diagram for: (a) wet season; (b) dry season, groundwater samples.

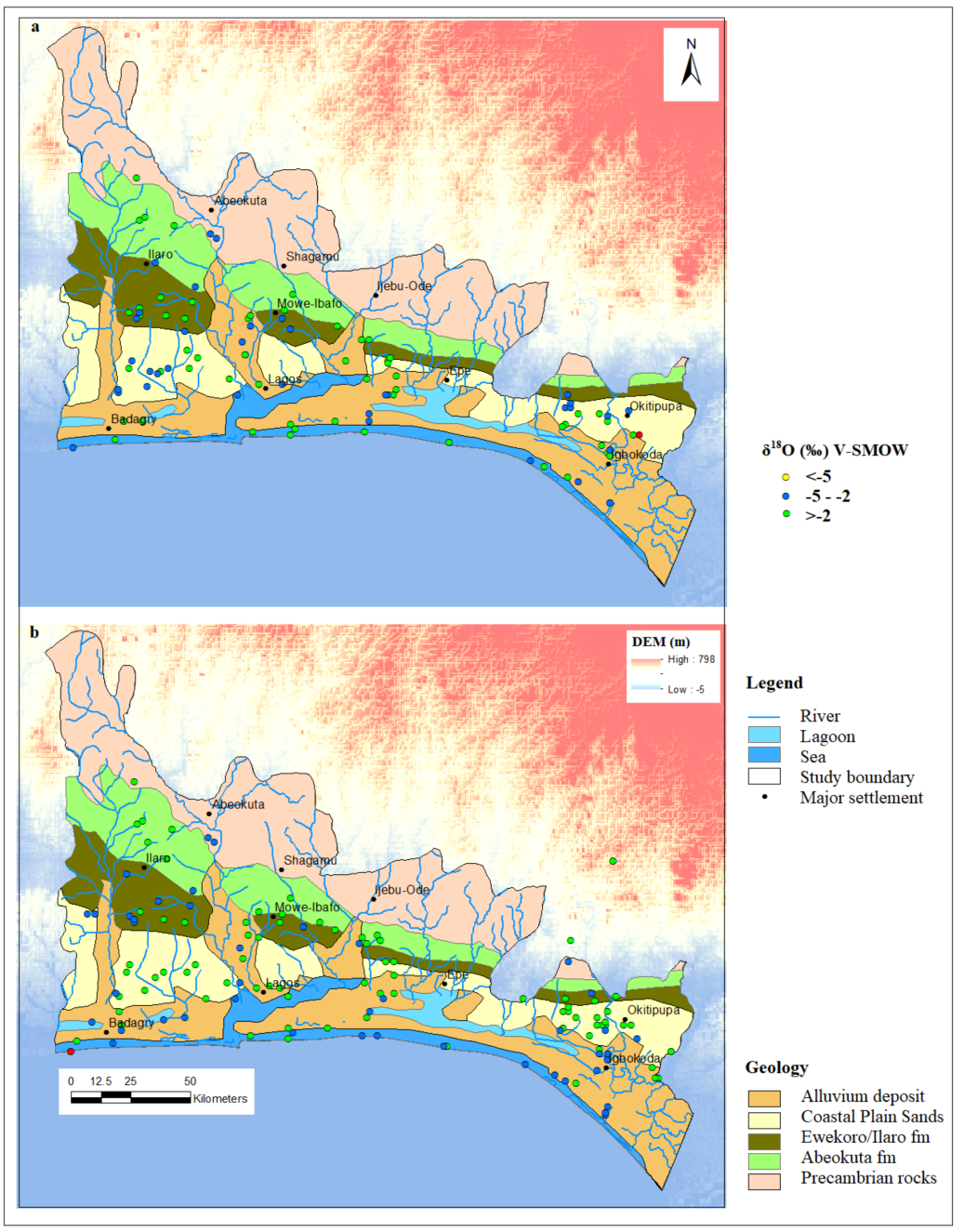

Figure 11. Spatial distribution map of $\delta^{18} \mathrm{O}(\%$ o) for the: (a) wet season; (b) dry season groundwater samples. 


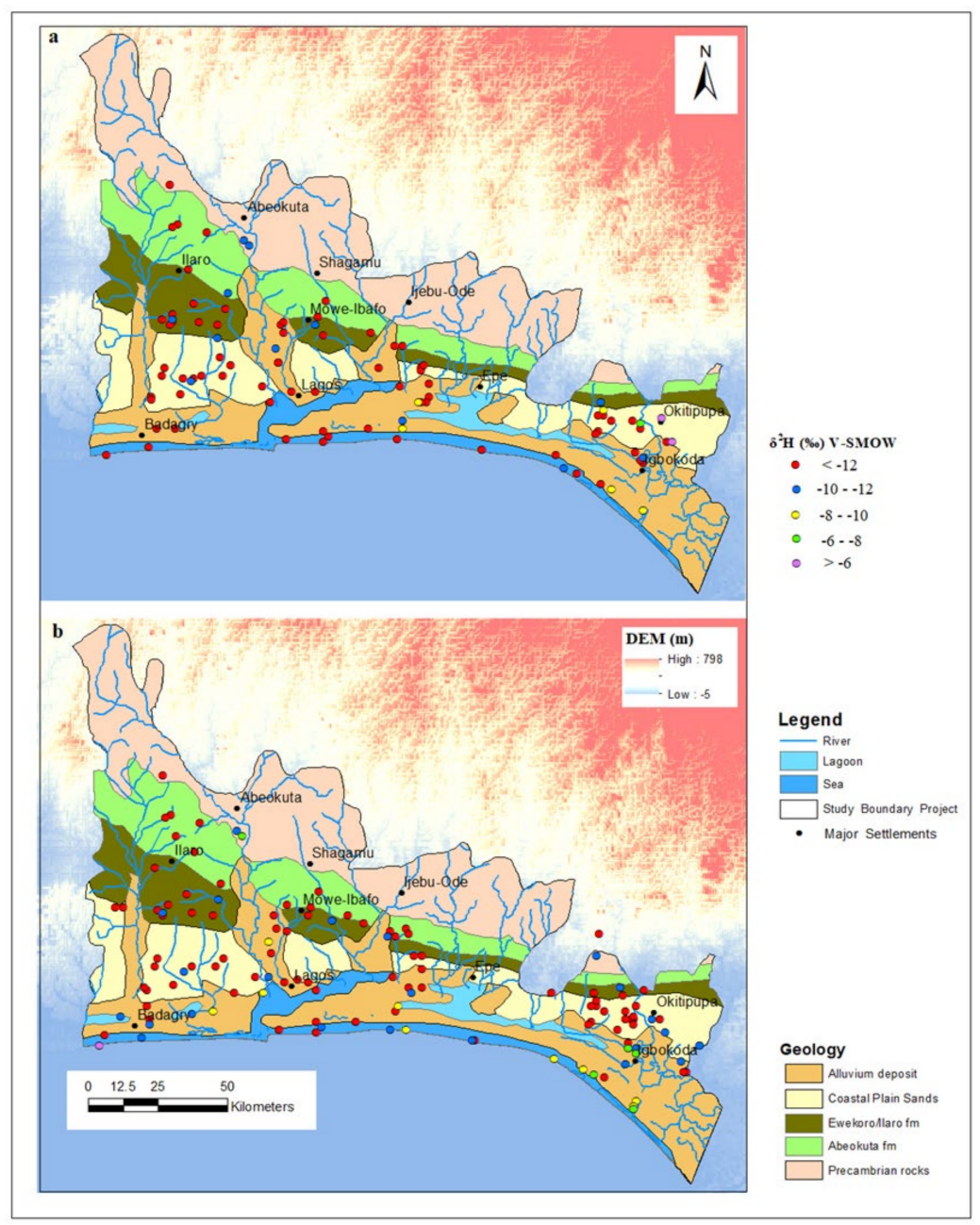

Figure 12. Spatial distribution map of $\delta^{2} \mathrm{H}(\%$ ) for the: (a) wet season; (b) dry season groundwater.

The wet season $\delta \mathrm{D} / \delta^{18} \mathrm{O}$ diagram (Figure 10) showed a more extensive range along the Local Meteoric Water Line (LMWL), which indicated precipitation dominant, with rapid infiltration into the shallow coastal aquifers of the basin [49]. Compared to dry season samples plotted within a shorter/narrow range, which tend towards mixed water with significant influence of evaporation before infiltrating into the shallow phreatic aquifers of the basin. Integrating precipitation $\delta^{2} \mathrm{H}$ and $\delta^{18} \mathrm{O}$ isotopes data with groundwater results from the EDB can enhance understanding of the origin of groundwater given hydrodynamic complexities resulting from the influence of multiple factors from both geology and environment. Unfortunately, the only station of International Atomic Energy Agency (IAEA)/World Meteorological Organization (WMO) GNIP sited in Nigeria is in the northern part in the city of Kano in the Sahel savannah. Due to the different climatic condition around this station, it is not ideal, relating such data with the coastal zones groundwater isotopes data. $\delta^{18} \mathrm{O}$ and $\delta \mathrm{D}$ in precipitation from two selected stations, Douala in Cameroon, in the east of EDB, and Cotonou in the Republic of Benin, and located in the west of the studied basin, were used for evaluations and analysis. The statistical summary of the isotopes in precipitation data as presented in Table 2, is part of the continuous temporal record of monthly mean $\delta^{2} \mathrm{H}$ and $\delta^{18} \mathrm{O}$ for rainfall measurements between 2009 and 2018. The $\delta^{2} \mathrm{H}$ and $\delta^{18} \mathrm{O}$ isotopes in precipitation from these selected GNIP stations are plotted in $\delta \mathrm{D} / \delta^{18} \mathrm{O}$ diagram (Figure 13) with a view to assess the possible influence of climatic and other effects such as altitude and continental factor on both $\delta^{2} \mathrm{H}$ and $\delta^{18} \mathrm{O}$ enrichment/depletion. 
Table 2. Summary of the stable isotopes data from the three GNIP stations and groundwater samples.

\begin{tabular}{|c|c|c|c|c|}
\hline Isotopes & Minimum & Maximum & Average & Std Dev \\
\hline & \multicolumn{4}{|c|}{ Douala GNIP Station $n=50$} \\
\hline$\delta^{18} \mathrm{O}$ & -6.14 & 1.77 & -2.54 & 1.57 \\
\hline$\delta^{2} \mathrm{H}$ & -38.80 & 17.68 & -9.05 & 11.89 \\
\hline \multirow[t]{2}{*}{ D-excess } & 2.60 & 18.87 & 11.26 & 3.70 \\
\hline & \multicolumn{4}{|c|}{ Cotonou GNIP Station $n=50$} \\
\hline$\delta^{18} \mathrm{O}$ & -5.53 & 1.82 & -2.86 & 1.63 \\
\hline$\delta^{2} \mathrm{H}$ & -36.11 & 15.76 & -11.92 & 11.74 \\
\hline \multirow[t]{2}{*}{ D-excess } & 0.30 & 17.44 & 10.99 & 3.30 \\
\hline & \multicolumn{4}{|c|}{ Kano GNIP Station } \\
\hline$\delta^{18} \mathrm{O}$ & -7.70 & 2.40 & -2.92 & 2.59 \\
\hline$\delta^{2} \mathrm{H}$ & -58.30 & 22.30 & -16.30 & 19.36 \\
\hline \multirow[t]{2}{*}{ D-excess } & -13.38 & 20.98 & 7.08 & 6.69 \\
\hline & \multicolumn{4}{|c|}{ Groundwater Samples Wet Season $n=97$} \\
\hline$\delta^{18} \mathrm{O}$ & -5.2 & 0.3 & -0.3 & 0.6 \\
\hline$\delta^{2} \mathrm{H}$ & -32.5 & 2.3 & -13.1 & 3.6 \\
\hline \multirow[t]{2}{*}{ D-excess } & -0.3 & 13.8 & 11.0 & 1.7 \\
\hline & \multicolumn{4}{|c|}{ Groundwater Samples Dry Season $n=133$} \\
\hline$\delta^{18} \mathrm{O}$ & -4.0 & 0.8 & -3.0 & 0.5 \\
\hline$\delta^{2} \mathrm{H}$ & -19.7 & 7.5 & -12.4 & 2.8 \\
\hline D-excess & 0.9 & 15.0 & 11.9 & 1.6 \\
\hline
\end{tabular}

The groundwater samples for wet and dry seasons plotted along with the meteoric water line for Douala (Cameroon), Cotonou (Republic of Benin) and Kano (Nigeria) and presented in Figure 14. The results show the groundwater samples clustering within the boundaries of the three Regional Meteoric Water Lines (RMWL) with slope values falling below the GMWL (Figure 12). This further reveals a large number of groundwater samples around the GMWL which indicates that meteoric water is a significant source of groundwater recharge in the study area. The Regional Meteoric Water Line (RMWL) characterising coastal precipitation from Cotonou $\left(\delta \mathrm{D}=7 \delta^{18} \mathrm{O}+8.0\right)$ and Douala $\left(\delta \mathrm{D}=7.2 \delta^{18} \mathrm{O}+9.3\right)$ are very close to the Global Meteoric Water Line (Figure 13). However, the stable isotopes data from the Kano station $\left(\delta \mathrm{D}=7.1 \delta^{18} \mathrm{O}+4.3\right)$ which has a slope closer to the GMWL but with lower $\delta \mathrm{D}$ intercept, indicates a climate effect of the region with relatively higher temperature and consequently higher evaporation rate with deuterium enrichment.

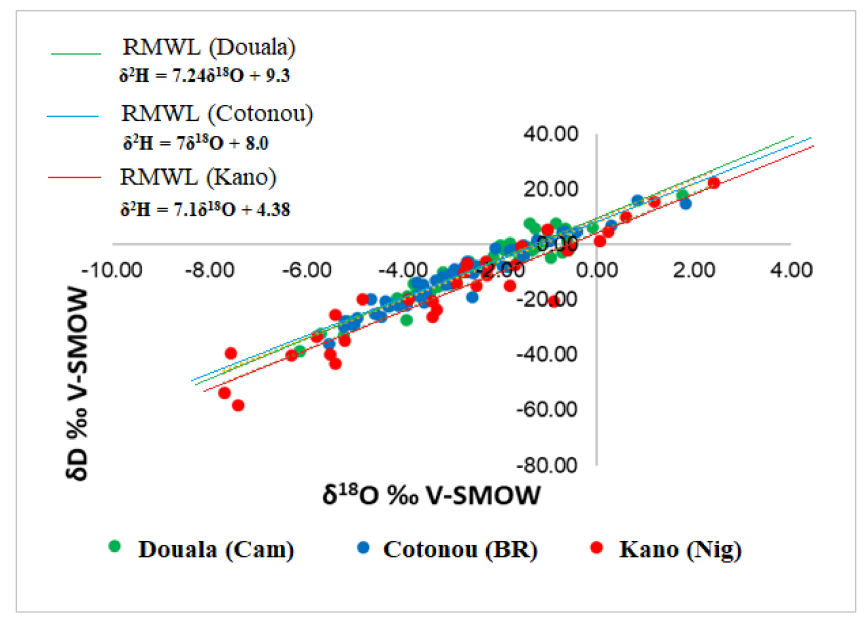

Figure 13. $\delta \mathrm{D}$ vs. $\delta 18 \mathrm{O}$ diagram for the selected regional precipitation data. 
The $\delta^{2} \mathrm{H}$ and $\delta^{18} \mathrm{O}$ data for the groundwater collected during the wet $\left(\delta \mathrm{D}=6.1 \delta^{18} \mathrm{O}+5.2\right)$ and dry $\left(\delta \mathrm{D}=5.4 \delta^{18} \mathrm{O}+4.1\right)$ seasons are presented in Figure 14. Groundwater from the EDB for both seasons falls almost along the same meteoric waterline with a slight difference in slopes and deuterium intercepts. The slopes and intercepts of the regression line are lower compared to the GMWL $\left(\delta \mathrm{D}=8^{*} \delta^{18} \mathrm{O}+10\right)$ indicating the effect of evaporative enrichment on groundwater driven by seasonal variations in precipitation and temperature.

The results of the stable isotope values of $\delta \mathrm{D}, \delta^{18} \mathrm{O}$, and D-excess in precipitation from the three selected GNIP stations compared with those of the groundwater from the shallow coastal aquifers of the EDB is presented in Table 2. The results of the wet season groundwater show a range of values $\delta^{18} \mathrm{O}(-5$ to $0.3 \%$ o), $\delta \mathrm{D}(-32$ to $2.3 \%$ o), and D-excess ( -0.3 to $13.8 \%$ o), which are very similar to those of Douala $\delta^{18} \mathrm{O}\left(-6.1\right.$ to $1.8 \%$ o), $\delta \mathrm{D}\left(-38\right.$ to $17.6 \%$ ), and D-excess (2.6 to $18.9 \%$ ), and Cotonou $\delta^{18} \mathrm{O}(-5.5$ to $1.8 \%$ o), $\delta \mathrm{D}$ (-36 to $15.8 \%$ o), and D-Excess ( 0.3 to $17.4 \%$ o), which could be a result of a similar climatic condition, especially temperature, humidity, and evaporation. However, the values of stable isotope of $\delta \mathrm{D}, \delta^{18} \mathrm{O}$, and D-excess values for the groundwater samples in the dry season show range values $\delta^{18} \mathrm{O}(-4$ to $0.8 \%$ o), $\delta \mathrm{D}(-19.7$ to $7.5 \%$ o), and D-excess (-0.9 to $15 \%$ o) with slight deviations from the wet season data. The observed slight variation is an indication of the evaporation effect, which is also responsible for the relatively enhanced values of TDS in a dry season's groundwater samples.

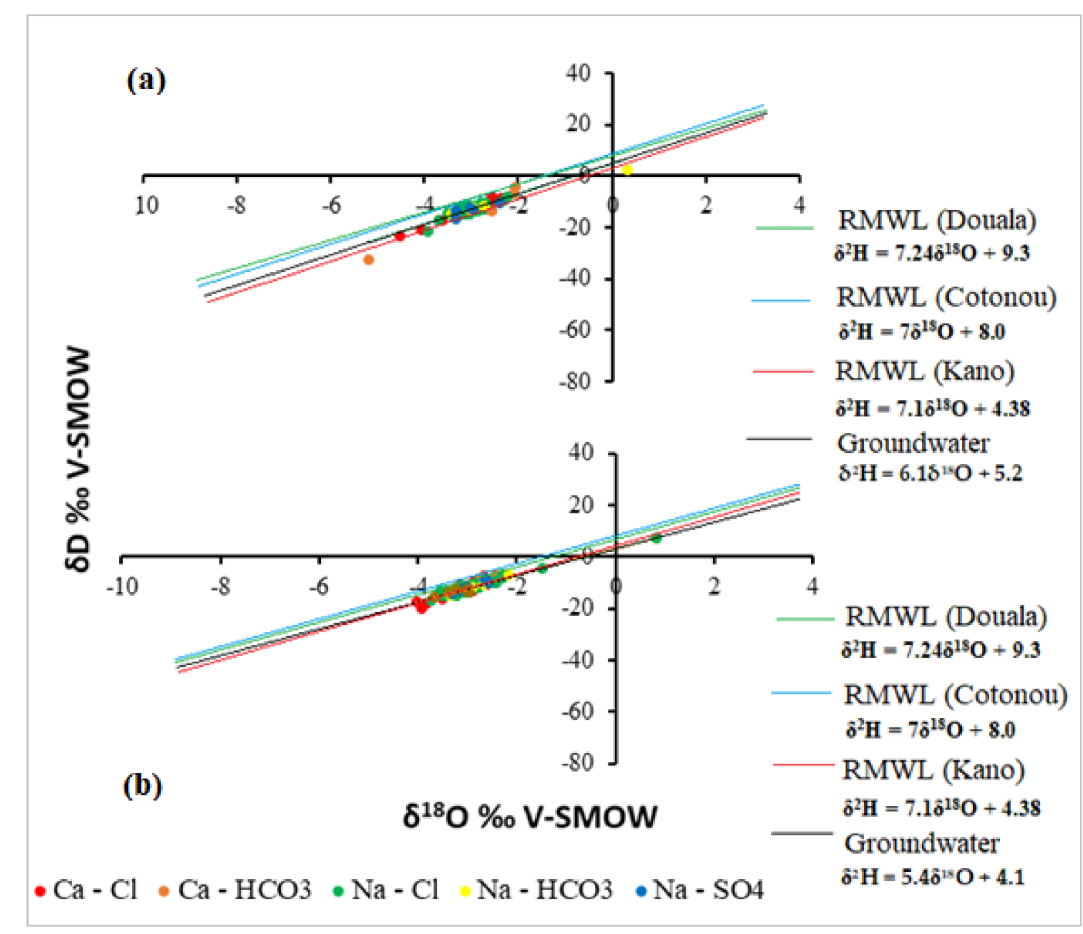

Figure 14. $\delta^{2} \mathrm{H}$ vs. $\delta^{18} \mathrm{O}$ diagram for selected precipitation data and the groundwater samples: (a) wet season; (b) dry season.

The precipitation isotopes data from the Kano GNIP station in the northern part of Nigeria (Table 2) with range values of $\delta^{18} \mathrm{O}$ ( -7 to $2.4 \%$ ),$\delta \mathrm{D}$ ( -58.3 to $22.3 \%$ ), and D-excess ( -13.4 to $21 \%$ o) showed a wide variation from those of Douala and Cotonou (Figure 13). This variation is probably due to the elevation effect in addition to the relatively higher elevation and evaporation rate in the northern part of Nigeria, which is characterised by low annual precipitation, as shown in Figure 1. The clustering of the groundwater samples around the Douala and Cotonou Regional Meteoric Water Line (RMWL) and Global Meteoric Water Line (GMWL) (Figures 13 and 14) affirm meteoric water that infiltrates the aquifer within a short time 


\subsection{Tracing the Origin of Groundwater within the EDB Using Deuterium Excess}

Deuterium excess (D-excess) is a useful measure to understand the source of groundwater. The D-excess is defined as D-excess $=\delta^{2} \mathrm{H}-8 \delta^{18} \mathrm{O}[20,28,50]$. The D-excess is a function of prevailing conditions during primary evaporation, including variation in humidity, ocean surface temperature, wind speed and, thus, gives information on the sources of water vapour. The D-excess does not change with the change in equilibrium processes for any of the phases while non-equilibrium evaporation leads to a decrease in the D-excess, which is an indication of an increase in the vapour phase $[18,20,28]$.

In this study, the D-excess values for groundwater in the wet season is slightly lower than that of the dry season. The higher D-excess in the dry season (Figure 15), is for samples collected between February and April 2017. During this period, a dry southward wind leads to the recycling of moisture from the continental recycling along with the rapid evaporation over warmer seawater responsible. This compares with plots of $\delta^{18} \mathrm{O}$ vs. D-excess in Figure 16, which also showed the clustering of D-excess in relation to rain, sea and brackish water plot from the basin. The diagrams showed that most of the groundwater of the wet season plotted closer to the precipitation, which is the source of the groundwater recharge and forms a trend towards the brackish point as evaporation increases.

The $\delta^{18} \mathrm{O}$ vs. D-excess diagram shows most groundwater samples plot in a region between the recharge and evaporation zones reflecting young water of meteoric origin at an early transformation stage through evaporation. This suggests precipitation water moving towards groundwater storage through the vadose zone is rapid. That post-precipitation evaporation along these paths is a prolonged process, probably due to higher humidity and precipitation that characterised this region. 


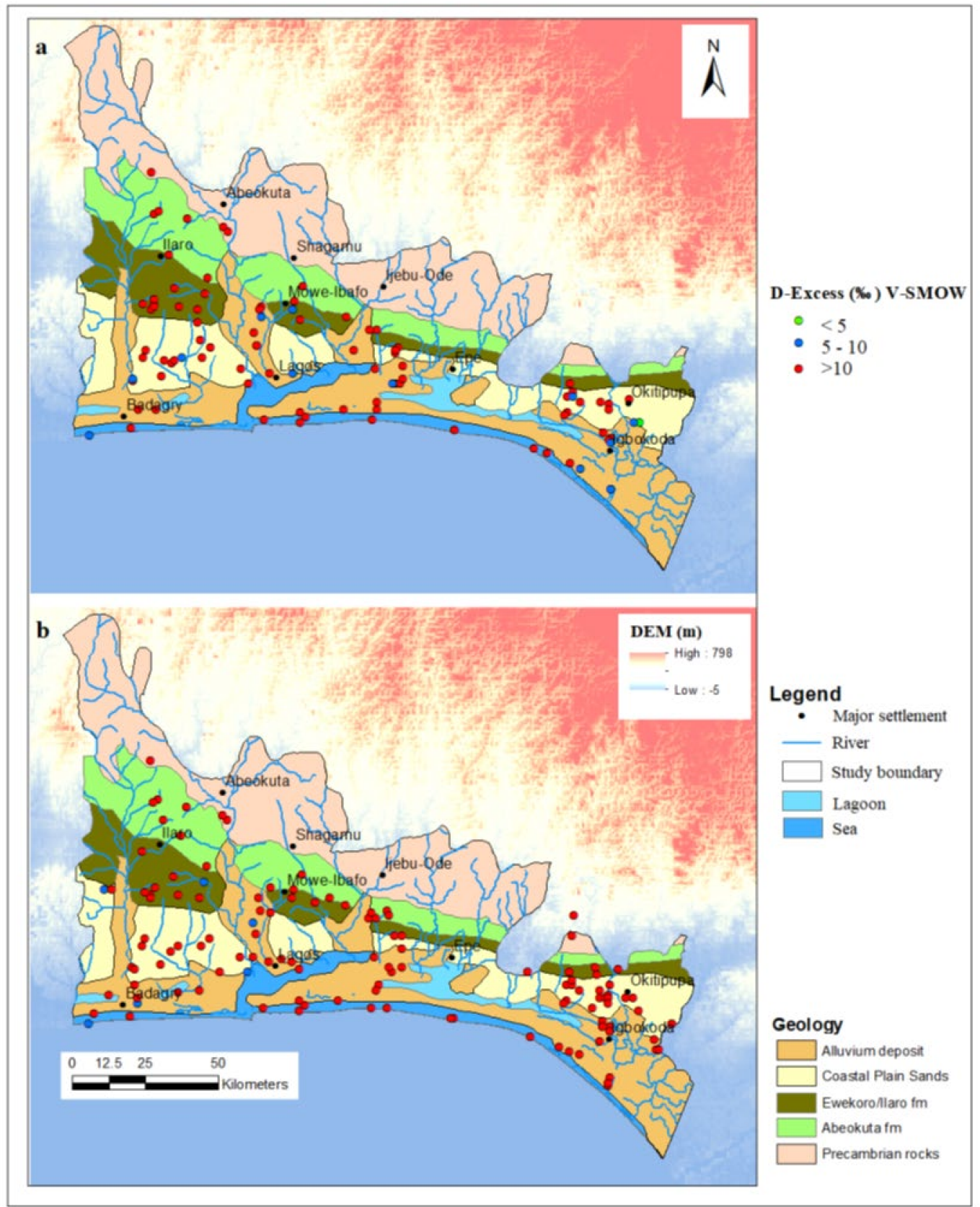

Figure 15. Spatial distribution map of D-excess (\%o) for the: (a) wet season; (b) dry season groundwater samples. 


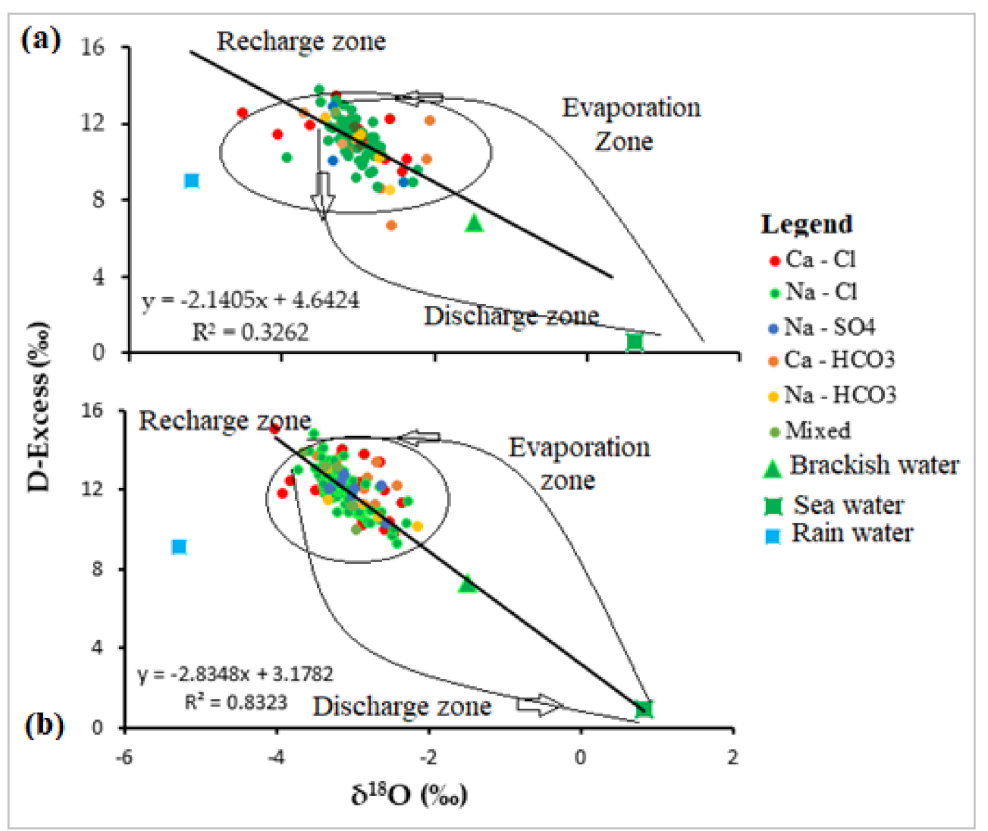

Figure 16. A plot of $\delta^{18} \mathrm{O}$ vs. D-excess for the groundwater samples: (a) wet season; (b) dry season.

3.4. Description of Conceptual Design of Hydrogeochemical Characterisation of the Shallow Coastal Aquifer of $E D B$

The results from this study have established the hydrochemical dynamic and process prevalent in the eastern Dahomey Basin, which shows a subtle transformation as water moves from the recharge zones in the northern part towards the discharge area in the downstream along the river channels and flood plains. The clustering of groundwater samples between evaporation and recharge and along the seawater line $\delta^{18} \mathrm{O}$ vs. D-excess diagram (Figure 16) confirmed young groundwater in the basin. The slight variations in the distribution of the $\delta \mathrm{D}$ and $\delta^{18} \mathrm{O}$ values and clustering along the regional meteoric water line (RMWL) and Global Meteoric Water Line (GMWL) with a slight deviation of the dry season groundwater further confirmed the recent water's short residence time within the soil and vadose zones before recharging the shallow coastal aquifer of the basin. The information from (a) the geological field observations, (b) groundwater levels, (c) elevation data, (d) aquifer geometry, (e) hydrochemical evolution, (f) spatial variability of $\delta^{18} \mathrm{O}, \delta \mathrm{D}$, and D-excess, (g) river and static water level, and (h) line of a cross-section along representative profile were collected and integrated to develop a conceptual outlook for the prevailing hydrogeological processes within the eastern Dahomey Basin, with well-defined boundary conditions of impermeable basement rock at the north, and the ocean line of the Gulf of Guinea in the south, enclosed by the flow boundary of the Okitipupa ridge in the east, and extended sedimentary deposits [49]. The flow systems within this area can be categorised into mainly local, driven by gravity due to the topography of the basin [38]. Some regional flow relates to the major rivers which cut across the entire basin, with several tributaries and discharge water into the ocean through the delta plain. The hydrochemical model shows $\mathrm{Na}-\mathrm{Cl}$ as a dominant water type followed by $\mathrm{Ca}-\mathrm{HCO}_{3}$ with other mixed water types, such as $\mathrm{Ca}-\mathrm{Cl}, \mathrm{Na}-\mathrm{SO}_{4}$, $\mathrm{Na}-\mathrm{Cl}-\mathrm{HCO}_{3}$, and $\mathrm{Ca}-\mathrm{SO}_{4}$, which typifies an early stage of rock-water interactions and possible anthropogenic influence.

This conceptual view explains the lateral and vertical variations in groundwater $\delta^{18} \mathrm{O}, \delta \mathrm{D}$, and D-excess concentrations, controlled by factors such as high humidity, static water level within the basin, and significant anthropogenic influence from urbanisation, industrialisation, and agricultural irrigation in most parts of the study area. For example, the D-excess results show comparatively shorter residence time for groundwater moving through the vadose zone to the shallow aquifers of the basin, especially within the alluvium and coastal plain sands geologic units (Figures 16-18). 
Observed hydrochemical characteristics across the basin generally reflect the geology and mineralogy of the area, while the lack of consistencies in groundwater isotope values and water type distribution could be attributed to heterogeneity and anthropogenic impacts along the flow paths. Furthermore, as illustrated in the schematic diagram in Figure 18, water recharged in the northern parts of the basin has to travel deeper as the vadose zone thickness is higher in this area. A certain amount of this infiltrated water recharges local rivers as baseflow while the remaining one recharges the groundwater in the shallow aquifers of the basin.

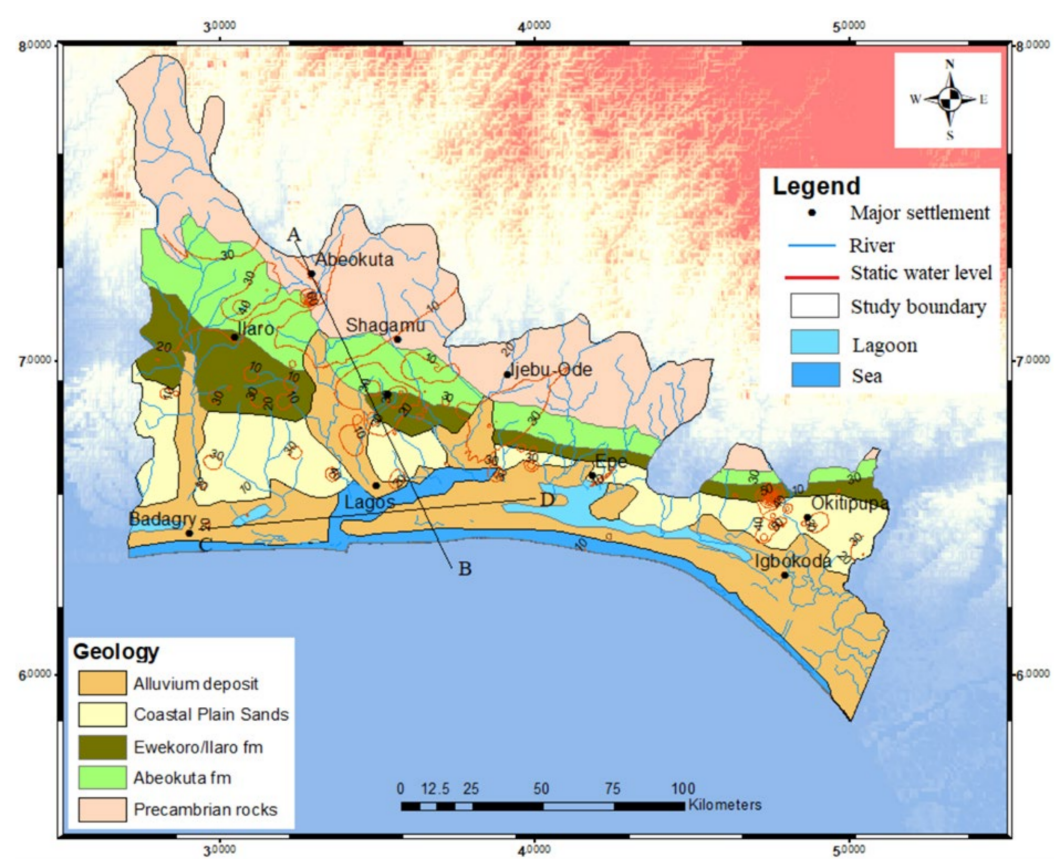

Figure 17. Map of the eastern Dahomey Basin showing contour line of static water level and rivers drainage with profile line $\mathrm{AB}$ along which the geological profile section was generated for the conceptual description of hydrogeochemical characterisation of the shallow aquifers underlying the eastern Dahomey Basin.

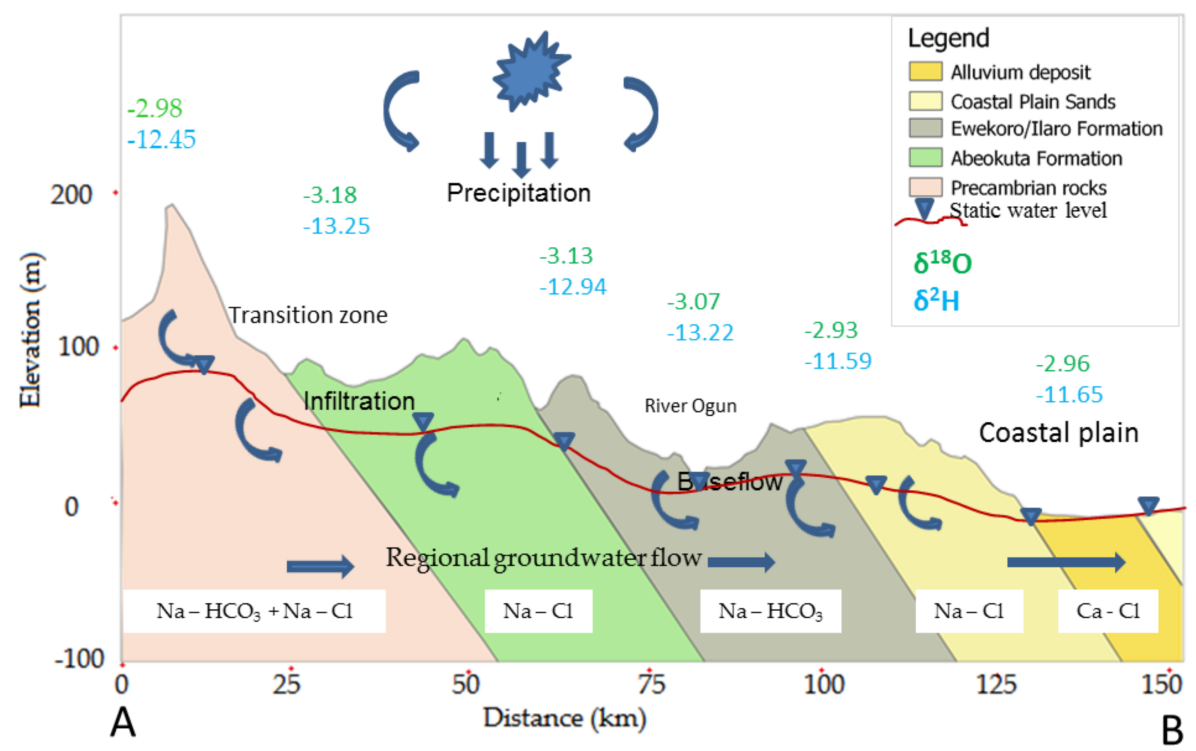

Figure 18. A sketch of a conceptual description of stable isotopes of $\delta^{2} \mathrm{H}$ and $\delta^{18} \mathrm{O}$ in groundwater samples along profile line A-B in North-South direction of the eastern Dahomey Basin. 


\subsection{The Implication for EDB Groundwater Resources Management}

Sustainable management of groundwater is critical to achieving access to potable water supply, food security, ecosystem/environmental protection and economic growth in sub-Saharan Africa countries [51]. Effective groundwater resources management relies on sound hydrogeological knowledge and ultimately on the quality of available data and information necessary for accurate judgement and planning.

In light of this, our study has advanced the available data, information and knowledge required to understand better the hydrogeology of the eastern Dahomey Basin, Nigeria. A combination of isotopes, geology, and hydrogeochemical approaches have revealed the groundwater is at an early stage of geochemical evolution with short residence time. However, the basin has a large volume of water with variable aquifer hydraulic characteristics. It is therefore pertinent to emphasise the threat to its water quality as short residence time, and rapid recharge will allow rapid ingress of contamination. The shallow aquifers of this basin are, thus, described as having a low resilience and high vulnerability to contamination and pollution from surface water, leakage from septic tanks, waste sites, industrial pipes, and leachates from agricultural waste. Groundwater quality degradation has been identified in part of this basin, especially the urban and agricultural areas by [21,52]. It is, therefore, necessary to ensure enforcement of a proper waste disposal management strategy that will protect groundwater within this basin. Policies and urban planning that provide best practice from industries and agricultural industries are necessary to protect these vital resources. A review of the existing Integrated Water Resource Management (IWRM) system is needed to include threats imposed on groundwater resources through technological development in the modern economy.

\section{Conclusions}

This study was a hydrogeochemical study covering the major towns and cities underlying the eastern Dahomey Basin using stable isotopes of $\delta^{18} \mathrm{O}, \delta \mathrm{D}$, and geochemistry. Static water levels were used to identify the recharge sources and zones, and also characterise groundwater dynamics in relation to stable isotopes in the shallow coastal aquifers of the basin. $\mathrm{Na}-\mathrm{Cl}$ is the dominant water type followed by $\mathrm{Ca}-\mathrm{HCO} 3, \mathrm{Na}-\mathrm{HCO} 3, \mathrm{Ca}-\mathrm{SO} 4$, and $\mathrm{Na}-\mathrm{SO} 4$ with other mixing water types, such as $\mathrm{Ca}-\mathrm{Cl}$, $\mathrm{K}-\mathrm{Cl}$, and $\mathrm{Mg}-\mathrm{SO} 4$. The dominant of the $\mathrm{Na}-\mathrm{Cl}$ water is thought to have two origins, namely sea spray and saltwater intrusion. Although these water types reflect the mineralogical characteristics of the aquifers' units within the basin, the lack of consistency distributed across the geologic unit is attributed to the heterogeneity within the aquifers and possible impact of human activities. Relationship between $\delta^{18} \mathrm{O}$ and $\delta \mathrm{D}$ revealed the wet season groundwater data plots closer to the Global Meteoric Water Line, while those of the dry season showed deviation towards evaporation. The relationship between the D-excess and $\delta^{18} \mathrm{O}$ clustered between the recharge and evaporation zone. Comparing the results with the regional precipitation data collected from the selected station of GNIP at Douala (Cameroon), Cotonou (Republic of Benin), and Kano (Nigeria) showed groundwater in the region is dominated by localised young water recharge with short residence time (with a slight influence of evapotranspiration), as expected with observed high static water tables. The variation of $\delta^{18} \mathrm{O}$ and $\delta^{2} \mathrm{H}$ has no consistent pattern along flow paths is an indication of the influence of multiple effects of altitude and temperature on the isotopic composition of the groundwater other than the normal evaporation. This study can help in both understanding aquifer resilience and vulnerability for developing a groundwater quality monitoring strategy for sustainable groundwater management in the eastern Dahomey Basin.

Author Contributions: Conceptualization, J.A.A., and R.M.K. methodology, J.A.A. R.M.K., M.N.T. and P.S. software, J.A.A. and I.H. validation, J.A.A., R.M.K. and I.H. formal analysis, J.A.A.; investigation, J.A.A. and M.N.T.; resources, J.A.A. and R.M.K. data curation, J.A.A., R.M.K. and I.H. writing-original draft preparation, J.A.A. writing-review and editing, J.A.A., R.M.K., I.H., M.N.T. and P.S. visualization, J.A.A. and I.H.; supervision, R.M.K. and P.S. project administration, R.M.K. and J.A.A. funding acquisition, J.A.A. and R.M.K. All authors have read and agreed to the published version of the manuscript. 
Funding: This research was funded by the Petroleum Technology and Development Fund (PTDF) under the Overseas PhD scholarship scheme and supported by the Scottish Government under the Climate Justice Fund Water Futures Program, awarded to the University of Strathclyde (R.M.K.).

Acknowledgments: The authors would like to gratefully acknowledge Ademola Ologbe, David Akpan, Mara Knapp, and Tatyana Peshkur for field and laboratory assistance.

Conflicts of Interest: The authors declare no conflict of interest.

\section{References}

1. Gattacceca, J.C.; Vallet-Coulomb, C.; Mayer, A.; Claude, C.; Radakovitch, O.; Conchetto, E.; Hamelin, B. Isotopic and Geochemical Characterization of Salinization in the Shallow Aquifers of a Reclaimed Subsiding Zone: The Southern Venice Lagoon Coastland. J. Hydrol. 2009, 378, 46-61. [CrossRef]

2. Guendouz, A.; Moulla, A.S.; Edmunds, W.M.; Zouari, K.; Shand, P.; Mamou, A. Hydrogeochemical and Isotopic Evolution of Water in the Complexe Terminal Aquifer in the Algerian Sahara. Hydrogeol. J. 2003, 11, 483-495. [CrossRef]

3. Daniele, L.; Vallejos, Á.; Corbella, M.; Molina, L.; Pulido-Bosch, A. Hydrogeochemistry and Geochemical Simulations to Assess Water-Rock Interactions in Complex Carbonate Aquifers: The Case of Aguadulce (SE Spain). Appl. Geochem. 2013, 29, 43-54. [CrossRef]

4. Kashaigili, J. J. Ground Water Availability and Use in Sub-Saharan Africa; CGIAR: Montpellier, France, 2012. [CrossRef]

5. Lapworth, D.J.; Nkhuwa, D.C.W.; Okotto-Okotto, J.; Pedley, S.; Stuart, M.E.; Tijani, M.N.; Wright, J. Urban Groundwater Quality in Sub-Saharan Africa: Current Status and Implications for Water Security and Public Health. Hydrogeol. J. 2017, 25, 1093-1116. [CrossRef]

6. Edet, A. Hydrogeology and Groundwater Evaluation of a Shallow Coastal Aquifer, Southern Akwa Ibom State (Nigeria). Appl. Water Sci. 2016, 7, 2397-2412. [CrossRef]

7. Oke, S.A.; Vermeulen, D.; Gomo, M. Aquifer Vulnerability Assessment of the Dahomey Basin Using the RTt Method. Environ. Earth Sci. 2016, 75, 1-9. [CrossRef]

8. Aladejana, J.A.; Kalin, R.M.; Sentenac, P.; Hassan, I. Hydrostratigraphic Characterisation of Shallow Coastal Aquifers of Eastern Dahomey Basin, S/W Nigeria, Using Integrated Hydrogeophysical Approach; Implication for Saltwater Intrusion. Geoscience 2020, 10, 65. [CrossRef]

9. Hoque, M.A.; Mcarthur, J.M.; Sikdar, P.K.; Ball, J.D.; Molla, T.N. Tracing Recharge to Aquifers beneath an Asian Megacity with $\mathrm{Cl} / \mathrm{Br}$ and Stable Isotopes: The Example of Dhaka, Bangladesh. J. Hydrol. 2014, 22, 1549-1560. [CrossRef]

10. Fathy, A. Ionic Ratios as Tracers to Assess Seawater Intrusion and to Identify Salinity Sources in Jazan Coastal Aquifer, Saudi Arabia. Arab. J. Geosci. 2016, 9, 40. [CrossRef]

11. Nwankwoala, H.O.; Ngah, S.A. Salinity dynamics: Trends and vulnerability of aquifers to contamination in the Niger Delta. Compr. J. Environ. Earth Sci. 2013, 2, 18-25.

12. Mohanty, A.K.; Rao, V.V.S.G. Catena Hydrogeochemical, Seawater Intrusion and Oxygen Isotope Studies on a Coastal Region in the Puri District of Odisha, India. Catena 2019, 172, 558-571. [CrossRef]

13. Lapworth, D.J.; Macdonald, A.M.; Tijani, M.N.; Darling, W. G.; Gooddy, D.C.; Bonsor, H.C. Residence Times of Shallow Groundwater in West Africa: Implications for Hydrogeology and Resilience to Future Changes in Climate. Hydrogeol. J. 2013, 21, 673-686. [CrossRef]

14. Kalin, R.M.; Long, A. Application of hydrogeochemical modelling for validation of hydrologie flow modelling in the Tucson Basin aquifer, Arizona, United States of America. In Mathematical Models and Their Applications to Isotope Studies in Groundwater Hydrology; TECDOC-777; IAEA: Viena, Austria, 1994; pp. 209-254.

15. Alazard, M.; Boisson, A.; Maréchal, J.; Perrin, J.; Dewandel, B.; Schwarz, T.; Pettenati, M.; Kloppman, W.; Ahmed, S. Investigation of Recharge Dynamics and Flow Paths in a Fractured Crystalline Aquifer in Semi-Arid India Using Borehole Logs: Implications for Managed Aquifer Recharge. Hydrogeol. J. 2015, 35-57. [CrossRef]

16. Huneau, F.; Dakoure, D.; Celle-Jeanton, H.; Vitvar, T.; Ito, M.; Traore, S.; Compaore, N.F.; Jirakova, H.; Le Coustumer, P. Flow Pattern and Residence Time of Groundwater within the South-Eastern Taoudeni Sedimentary Basin (Burkina Faso, Mali). J. Hydrol. 2011, 409, 423-439. [CrossRef] 
17. He, J.; Ma, J.; Zhao, W.; Sun, S. Groundwater Evolution and Recharge Determination of the Quaternary Aquifer in the Shule River Basin, Northwest China. Hydrogeol. J. 2015, 23, 1745-1759. [CrossRef]

18. Banda, L.C.; Rivett, M.O.; Kalin, R.M.; Zavison, A.S.K.; Phiri, P.; Kelly, L.; Chavula, G.; Kapachika, C.C.; Nkhata, M.; Kamtukule, S.; et al. Water-Isotope Capacity Building and Demonstration in a Developing World Context: Isotopic Baseline and Conceptualization of a Lake Malawi Catchment. Water 2019, 11, 2600. [CrossRef]

19. Krishnaraj, S.; Murugesan, V.K.V.; Sabarathinam, C.; Paluchamy, A.; Ramachandran, M. Use of hydrochemistry and stable isotopes as tools for groundwater evolution and contamination investigations. J. Geosci. 2012, 1, 16-25. [CrossRef]

20. Joshi, S.K.; Rai, S.P.; Sinha, R.; Gupta, S.; Densmore, A.L.; Rawat, Y.S.; Shekhar, S. Tracing Groundwater Recharge Sources in the Northwestern Indian Alluvial Aquifer Using Water Isotopes $(\Delta 18 \mathrm{O}, \Delta 2 \mathrm{H} A n d 3 \mathrm{H})$. J. Hydrol. 2018, 559, 835-847. [CrossRef]

21. Aladejana, J.A.; Kalin, R.M.; Sentenac, P.; Hassan, I. Assessing the Impact of Climate Change on Groundwater Quality of the Shallow Coastal Aquifer of Eastern Dahomey Basin, Southwestern Nigeria. Water 2020, 12, 224. [CrossRef]

22. Oke, S.A. Evaluation of the Vulnerability of Selected Aquifer Systems in the Eastern Dahomey Basin, South-Western Nigeria. Ph.D. Thesis, University of the Free State, Bloemfontein, South Africa, 2015.

23. Omole, D.O. Sustainable Groundwater Exploitation in Nigeria. J. Water Resour. Ocean Sci. $2013,2,9$. [CrossRef]

24. Ayoade, J.O. Water Resources and their Development in Nigeria Recent Events of Flood, Drought and Urban Water Shortages as Well as Water Pollution in Nigeria and Various Parts of the World Have Underlined the Need for the Rational Planning of Nigeria's Water Reso. Hydrol. Sci. Sci. Hydrol. 1975, 4, 581-591.

25. Ahmed, A.; Clark, I. Groundwater Flow and Geochemical Evolution in the Central Flinders Ranges, South Australia. Sci. Total Environ. 2016, 572, 837-851. [CrossRef] [PubMed]

26. Shin, W.J.; Park, Y.; Koh, D.C.; Lee, K.S.; Kim, Y.; Kim, Y. Hydrogeochemical and Isotopic Features of the Groundwater Flow Systems in the Central-Northern Part of Jeju Island (Republic of Korea). J. Geochem. Explor. 2017, 175, 99-109. [CrossRef]

27. Peter Bauer-Gottwein, B.N.; Gondwe, L.C.; Daan, H.; Kgotlhang, L.; Zimmermann, S. Hydrogeophysical exploration of three-dimensional salinity anomalies with the time-domain electromagnetic method (TDEM). J. Hydrol. 2010, 380, 318-329. [CrossRef]

28. Kalin, R.M. Basic Concepts and Formulations for Isotope-Geochemical Process Investigations, Procedures and Methodologies of Geochemical Modelling of Groundwater Systems. In Manual on Mathematical Models in Isotope Hydrology; Yurtsever, Y., Ed.; TECHDOC 910; IAEA: Vienna, Austria, 1995.

29. Clark, I.D.; Fritz, P. Environmental Isotopes in Hydrogeology; Lewis Publishers: Boca Raton, FL, USA, 1997.

30. Gagné, S.; Larocque, M.; Pinti, D.L.; Saby, M.; Meyzonnat, G.; Méjean, P. Benefits and Limitations of Using Isotope-Derived Groundwater Travel Times and Major Ion Chemistry to Validate a Regional Groundwater Flow Model: Example from the Centre-Du-Québec Region, Canada. Can. Water Resour. J. 2017, 1784, 1-19. [CrossRef]

31. Oloruntola, M.O.; Adeyemi, G.O.; Bayewu, O.; Obasaju, D.O. Hydro-Geophysical Mapping of Occurrences and Lateral Continuity of Aquifers in Coastal and Landward Parts of Ikorodu, Lagos, Southwestern Nigeria. Int. J. Energy Water Resour. 2019, 3, 219-231. [CrossRef]

32. Adelana, S.M.A.; Olasehinde, P.I.; Bale, R.B.; Vrbka, P.; Edet, A.E.; Goni, I.B. An Overview of the Geology and Hydrogeology of Nigeria. Q. J. Eng. Geol. Hydrogeol. 1996, 29, S1-S12. [CrossRef]

33. Adegoke, O.S.; Omatsola, M.E. Tectonic evolution and cretaceous stratigraphy of the Dahomey Basin. Niger. J. Min. Geol. 1981, 18, 130-137.

34. Jones, H.A; Hockey, R. The geology of part of Southwestern Nigeria. GSN Bull. 1964, 225, $229-237$.

35. Solomon, O.; Olabode1, M.Z.M. Depositional Facies and Sequence. Int J. Geosci. 2016, 7, $210-228$.

36. Longe, E.O.; Malomo, S.; Olorunniwo, M.A. Hydrogeology of Lagos Metropolis. J. African Earth Sci. 1987, 6, 163-174. [CrossRef]

37. Longe, E.O. Groundwater Resources Potential in the Coastal Plain Sands Aquifers, Lagos, Nigeria. Res. J. Environ. Earth Sci. 2011, 3, 1-7.

38. Offodile, M.E. The Hydrogeology of Coastal Areas of Southeastern States of Nigeria. J. Min. Geol. 1971, 14, 94-101. 
39. Faleye, E.T.; Olorunfemi, M.O. Aquifer Characterization and Groundwater Potential Assessment of the Sedimentary Basin of Ondo State 1 2. Ife J. Sci. 2015, 17, 429-439.

40. Fatoba, J.O.; Omolayo, S.D.; Adigun, E.O. Using Geoelectric Soundings for Estimation of Hydraulic Characteristics of Aquifers in the Coastal Area of Lagos, Southwestern Nigeria. Int. Lett. Nat. Sci. 2014, 11, 30-39. [CrossRef]

41. Adeoti, L.; Alile, O.M.; Uchegbulam, O. Geophysical Investigation of Saline Water Intrusion into Freshwater Aquifers: A Case Study of Oniru, Lagos State. Sci. Res. Essays 2010, 5, 248-259.

42. Oteri, A.U.; Atolagbe, F.P. Saltwater Intrusion into Coastal Aquifers in Nigeria. In Proceedings of the Second International Conference on Saltwater Intrusion and Coastal Aquifers-Monitoring, Modeling, and Management, Yucatán, México, 30 March-2 April 2003; pp. 1-15.

43. Dehnavi, A.; Sarikhani, R.; Nagaraju, D. Hydro Geochemical and Rock Water Interaction Studies in East of Kurdistan, NW of Iran. Int. J. Env. Sci. Res. 2011, 1, 16-22.

44. Fu, C.; Li, X.; Ma, J.; Liu, L.; Gao, M.; Bai, Z. A Hydrochemistry and Multi-Isotopic Study of Groundwater Origin and Hydrochemical Evolution in the Middle Reaches of the Kuye River Basin. Appl. Geochem. 2018, 98, 82-93. [CrossRef]

45. Narany, T.S.; Ramli, M.F.; Aris, A.Z.; Nor, W.; Sulaiman, A.; Juahir, H.; Fakharian, K. Identification of the Hydrogeochemical Processes in Groundwater Using Classic Integrated Geochemical Methods and Geostatistical Techniques, in Amol-Babol Plain, Iran. Sci. World J. 2014, 2014, 1-15. [CrossRef]

46. Oli, I.C.; Okeke, O.C.; Abiahu, C.M.G.; Anifowose, F.A.; Fagorite, V.I. A review of the geology and mineral resources of Dahomey basin, southwestern Nigeria. Int. J. Environ. Sci. Nat. Res. 2019, 21, 556055. [CrossRef]

47. Al-Charideh, A.; Kattaa, B. Isotope Hydrology of Deep Groundwater in Syria: Renewable and Non-Renewable Groundwater and Paleoclimate Impact. Hydrogeol. J. 2016, 24, 79-98. [CrossRef]

48. Carol, E.; Kruse, E.; Mas-Pla, J. Hydrochemical and Isotopical Evidence of Ground Water Salinization Processes on the Coastal Plain of Samborombon Bay, Argentina. J. Hydrol. 2009, 335-345. [CrossRef]

49. Jamiu, A.A.; Kalin, R.M.; Hassan, I.; Sentenac, P. Hydrogeochemical and isotopic characterization of coastal groundwater of eastern dahomey basin, Southwestern Nigeria. Geosciences 2020, 26, 65-71.

50. Vengosh, A.; Hening, S.; Ganor, J.; Mayer, B.; Weyhenmeyer, C.E.; Bullen, T.D.; Paytan, A. New Isotopic Evidence for the Origin of Groundwater from the Nubian Sandstone Aquifer in the Negev, Israel. Appl. Geochem. 2007, 22, 1052-1073. [CrossRef]

51. JICA. The Project for Review and Update of Nigeria National Water Resources; Federal Republic of Nigeria: Abuja, Nigeria, 2014.

52. Aladejana, J.A.; Kalin, R.M.; Sentenac, P.; Hassan, I. Groundwater Quality Index as a Hydrochemical Tool for Monitoring Saltwater Intrusion into Coastal Freshwater Aquifer of Eastern Dahomey Basin, Southwestern Nigeria. Groundw. Sustain. Dev. 2020, 25, under review. [CrossRef]

Publisher's Note: MDPI stays neutral with regard to jurisdictional claims in published maps and institutional affiliations.

(C) 2020 by the authors. Licensee MDPI, Basel, Switzerland. This article is an open access article distributed under the terms and conditions of the Creative Commons Attribution (CC BY) license (http://creativecommons.org/licenses/by/4.0/). 